\title{
STUDIES ON THE MECHANISM OF HYPERSENSITIVITY PHENOMENA
}

\author{
III. The Participation of Complement in the Formation \\ OF ANAPHYLATOXIN*
}

By ABRAHAM G. OSLER, PH.D., HARRY G. RANDALL, BETSY M. HILL, AND ZOLTAN OVARY, M.D.

(From the Department of Microbiology, The Johns Hopkins School of Medicine, and School of Hygiene and Public Health and the Department of Medicine, The Johns Hopkins School of Medicine, Baltimore)

(Received for publication, April 10, 1959)

Previous studies of passive cutaneous anaphylaxis (PCA $)^{1}$ in the albino rat led to the concept that this allergic tissue response was mediated in part by a host factor resembling complement $\left(C^{\prime}\right)(1)$. Subsequently, the thesis was advanced that allergic reactions of the immediate type occurred at a cell surface where molecules of attached antibody reacted with antigen in the presence of an excess of $\mathrm{C}^{\prime}$ provided by the circulating blood. This interpretation of the experimental data was not considered to be unique in view of the technical complexities and theoretical limitations associated with experiments in the intact animal $(2,3)$. These considerations have led to a more detailed study of an in vitro model as an additional effort to define more precisely the role of $\mathrm{C}^{\prime}$ in anaphylactic reactions. This model is derived from the studies of Friedberger, Bordet, Novy, and de Kruif (see reference 2 for review of earlier literature) and is based on the utilization of a cell-free reaction system comprising antigen, antibody, and fresh serum. The importance of this model pertains to the observation that the loss of hemolytic potency following antigenantibody interaction in fresh serum is also associated with the genesis of a substance(s) called anaphylatoxin which is endowed with the capacity to

\footnotetext{
* Presented in part at the annual meeting of the American Academy of Allergy, Chicago, 1959, and before the American Association of Immunologists, Atlantic City, 1959. This investigation was carried out under the auspices of the Commission on Cutaneous Diseases of the Armed Forces Epidemiological Board, and was supported in part by the Office of The Surgeon General, Department of the Army, and in part by the National Science Foundation and the American Heart Association. Part of the studies were also carried out under terms of a contract between Fort Detrick, Frederick, Maryland, and the School of Medicine, The Johns Hopkins University.

${ }^{1}$ PCA, passive cutaneous anaphylaxis.
} 
contract smooth muscle and augment capillary or minute vessel permeability. Although the use of this model system may be regarded as an oversimplified and perhaps tangential approach to the study of anaphylactic phenomena, its present application has resulted in several pertinent findings with respect to the mechanism of these reactions. The use of a cell-free reaction medium also effects a physical separation of those processes which lead to the formation of a substance injurious to tissues from those concerned with the tissue responses engendered by it. The study of each of these reaction sequences is thereby facilitated. Further, the product of these $\mathrm{C}^{\prime}$ fixation reactions may be characterized in terms of those tissue responses intimately associated with allergic reactions of the immediate type, the capacity to contract smooth muscle and to enhance capillary permeability $(4-7)$. The experiments described in this report may be considered to offer the type of evidence required to establish a sequential and causal relationship between the fixation of $\mathrm{C}^{\prime}$ and those processes ascribed to the tissue injury characteristic of allergic reactions of the immediate type.

\section{Materials and Methods}

The basic experimental design for these studies can be briefly outlined as follows. Antigen and antibody were added as preformed immune aggregates (PIA) ${ }^{2}$ to fresh rat or guinea pig serum under the experimental conditions designated below. At appropriate time intervals, aliquots of these reaction mixtures were centrifuged at approximately $12,000 \mathrm{~g}$ for 30 minutes at $0^{\circ} \mathrm{C}$. and the supernates assayed for: (a) hemolytic potency, i.e., $\mathrm{C}^{\prime}$ fixation; (b) $\mathrm{C}^{\prime}$ activity; (c) capillary permeability enhancement in the guinea pig skin; and (d) ability to contract normal guinea pig ileum in a Schultz-Dale bath.

In most of the experiments, the $C^{\prime}$ fixation estimates were performed prior to centrifugation since it had been demonstrated that dilution of the reaction mixture in ice-cold buffer sufficed to arrest further $C^{\prime}$ utilization even in the initial stages of the fixation process (8). In some of the experiments all four assays were carried out on the same day. When this was not practicable, aliquots were removed for the $C^{\prime}$ fixation estimates, and the remainder of the supernates was centrifuged, diluted with an equal volume of $0.02 \mathrm{M} \mathrm{Na} \mathrm{HEDTA}^{\mathrm{a}}$ in isotonic sodium chloride, and stored in tightly stoppered glass vials at $-50^{\circ} \mathrm{C}$.

Preformed Immune Aggregates (PIA).-Many preliminary experiments were performed in which rabbit antisera were reacted with the appropriate antigens in fresh rat or guinea pig serum. For the experiments described in this report, the immune reactants were in the form of PIA except as noted in Table I. These preparations were preferred since they contained a minimum of extraneous serum and non-antigenic constituents. The following account describes a representative preparation. Rabbit anti-ovalbumin serum was obtained following immunization with a commercial, twice-crystallized ovalbumin (Ea) preparation ${ }^{4}$ in Freund adjuvants. The sera of three rabbits, bled at repeated intervals, were pooled and heated at $56^{\circ} \mathrm{C}$. for 30 minutes. This serum pool, labelled 134-6, was then clarified by centrifugation at $0^{\circ} \mathrm{C}$. for 60 minutes at $12,000 \mathrm{~g}$, and analyzed by the quantitative precipitin technique (9). To $25 \mathrm{ml}$. of

${ }^{2}$ PIA, preformed immune aggregates.

${ }^{3} \mathrm{NA}_{3} \mathrm{HEDTA}$, tridsodium ethylenediamine tetraacetate.

${ }^{4}$ Worthington Biochemical Corporation, Freehold, New Jersey. 
this antiserum containing 0.722 precipitable antibody $\mathrm{N}$ per ml., were added $4.9 \mathrm{ml}$. of a centrifuged Ea solution ( $0.352 \mathrm{mg}$. $\mathrm{N}$ per ml.) to attain an antibody: antigen ratio approximating 10.5. The equivalence zone ratio for these reagents was slightly lower; i.e., 9.5. The antiserum and Ea solution were thoroughly mixed and incubated at $37^{\circ} \mathrm{C}$. for 3 hours, centrifuged at $12,000 \mathrm{~g}$ and washed until the supernates were free of protein as judged by optical density measurements in a DU model Beckman spectrophotometer at $278 \mathrm{~m} \mu$. For this preparation three washings, each with $30 \mathrm{ml}$. of cold saline, sufficed. The washed precipitate was resuspended in $36 \mathrm{ml}$. of saline containing 0.1 per cent merthiolate and stored at $0^{\circ} \mathrm{C}$. Antibody $\mathrm{N}$ estimates for the PIA were determined for total $\mathrm{N}$ analyses by the micro-Kjeldahl method (9) or from optical density measurements in $0.25 \mathrm{M}$ acetic acid as described in (10) with the aid of appropriate conversion factors for the Ea solution and for rabbit antibody as given in reference 11, and as confirmed in this laboratory. For the preparation described above, the anti-Ea $\mathrm{N}$ content in the resuspended PIA was $0.450 \mathrm{mg}$. per ml. Appropriate dilutions were prepared as required.

Complement.-Pooled guinea pig and rat sera were used as the source of $\mathrm{C}^{\prime}$. The former was obtained commercially in the frozen state from the Hyland Laboratories, Los Angeles, and generally contained about $220 \mathrm{C}^{\prime} \mathrm{H}_{50}$ per ml. when titrated as described in reference 12 after absorption with packed sheep erythrocytes. Rat serum was obtained by exsanguinating albino rats of the Wistar strain, or commercially from the Hyland Laboratories. The pooled rat serum generally contained between 40 and $45 \mathrm{C}^{\prime} \mathrm{H}_{50}$ per ml. after absorption in the cold with washed, packed sheep erythrocytes. Further details regarding the preparation, storage, and estimation of $\mathrm{C}^{\prime}$ activity for lytic and $\mathrm{C}^{\prime}$ fixation potencies have been given in the previous report (1) as modified from that reported in reference 13 for application to rat serum.

$C_{3}^{\prime}$ Estimations. - These titrations were carried out by the method of Rapp (14) as modified in reference 15. The method is based on the observation of Costa Cruz and Azevedo Penna $(16,17)$ relative to the specific inactivation of $C_{3}^{\prime}$ by formaldehyde. For the purposes of this investigation, guinea pig serum was treated with formalin as outlined in reference 15 , and then reacted with sensitized sheep erythrocytes to yield the intermediate $\mathrm{EAC}_{1,4,2}^{\prime}$ as described by Mayer (18). These cells served as an appropriate substrate for estimations of $C_{3}^{\prime}$ activity in terms of $\mathrm{C}^{\prime} 3 \mathrm{H}_{60}$, the dilution of serum which will hemolyze 50 per cent of the $\mathrm{EAC}_{1,4,2}^{\prime}$ cells in the test carried out in the presence of $0.01 \mathrm{~m}$ EDTA (trisodium ethylenediamine tetraacetate, $\mathrm{Na}_{3} \mathrm{HEDTA}$ ). The number of $\mathrm{C}^{\prime} 3 \mathrm{H}_{50}$ in untreated and pooled rat serum has been found to vary between 120 and 180 in most of the experiments. This variation is due almost entirely to changes in susceptibility of the treated erythrocytes as prepared on different days. In view of this uncontrolled variation, the degree of $C_{8}^{\prime}$ inactivation attributable to a specific treatment has been estimated in terms of the potency of untreated rat serum included in each of the titration series.

Estimations of Capillary Permeability Changes.-These assays were carried out in male albino guinea pigs weighing 230 to $270 \mathrm{gm}$. (19). The fur on the backs of the animals was shaved the day before testing. In the test procedure, each animal received an intravenous injection of $1 \mathrm{ml}$. of 0.5 per cent Evans blue in saline and immediately thereafter, 6 intradermal injections of $0.1 \mathrm{ml}$. aliquots of the various test materials. The animal was sacrificed $60 \mathrm{~min}$ utes after the intradermal injections and the reactions measured with a transparent millimeter ruler placed over the blue spot on the inner surface of the skin. On the basis of many preliminary dose-response studies, it was concluded that valid comparisons between different treatments might best be made when the reaction mixtures were diluted in isotonic $\mathrm{NaCl}$ to yield a $1 \rightarrow 75$ final dilution of the rat serum used as a $C^{\prime}$ source. The value given for the diameter of the skin response obtained with each test substance in the tables below, represents an arithmetic mean of six replicates. Each replicate was randomized as to site and guinea pig in accord with a $6 \times 16$ incomplete Latin square, an experimental design recommended by Dr. 
Glenn E. Bartsch of the Biostatistics Department of the Johns Hopkins School of Hygiene and Public Health (20). The injection materials were coded and the reactions measured by two individuals. An "adjusted treatment mean" was calculated for each of the sixteen substances or treatments in every experiment. The sixteen values thus obtained could be compared by a single standard error of the difference irrespective of the differences in reactivity between guinea pigs and sites of inoculation. The precision inherent in data of this type may be indicated by the observation that the standard error of the difference between mean reaction diameters of different test substances ranged from 0.8 to $1.8 \mathrm{~mm}$. in individual sets of the many assays conducted during the course of this investigation.

It should be noted that these skin reactions are not comparable to PCA reactions such as reported in reference 1 . In the present situation a dilution of the reaction mixture is placed in the skin and results in a very rapid liberation of histamine or other permeability factors, without further intervention of antigen, antibody, or appreciable latent period. The areas of skin blueing become visible within a few minutes after injection. Despite the statistical and other methodological precautions, the total range of quantitation is limited to reactions with a minimum diameter of about $6 \mathrm{~mm}$. (produced by saline or untreated serum) to a maximum rarely exceeding 18 to $20 \mathrm{~mm}$. This relative compression of the range of observations sharply limited the ease in detecting some of the more subtle differences that were encountered in the other assay procedures.

The use of guinea pig serum for the study of capillary permeability changes induced by antigen-antibody interaction is attended by yet greater complexities than those discussed above for the rat serum. Reference is made to the possible interplay of multiple permeability factors and inhibitors, as described by Miles and Wilhelm (21, 22). On the basis of many experiments, it appeared that a valid assay procedure for permeability factors in experiments with guinea pig serum was potentially available when the precautions described in $(21,22)$ were followed. However, the lack of definitive knowledge as to the possible relationship between anaphylatoxin and the other permeability factors in guinea pig serum discouraged extensive efforts along these lines for the present.

Estimations of Smooth Muscle Contraction.-These assays have been carried out in a modified Schultz-Dale apparatus developed on the basis of an original design by Dr. Samuel A. Talbot and his associates in the Biophysics Division of the Department of Medicine at this institution. Details as to construction, operation, and validation of the assay technique are currently being assembled for publication (23). For present purposes it may be indicated that the contraction of segments of guinea pig ileum bathed in oxygenated Krebs buffer is measured under isometric conditions (24) with an RCA 5734 triode (25) transducer. Under these conditions, $0.4 \mu \mathrm{g}$. of histamine dihydrochloride in isotonic $\mathrm{NaCl}$, when added in a volume of 0.2 $\mathrm{ml}$. to the $20 \mathrm{ml}$. tissue bath, results in a tension increase sufficient to yield a reading of 60 to $70 \mathrm{~mm}$. or more on a G-10 varian recorder. Untreated rat serum in a volume of $0.2 \mathrm{ml}$. generally yields a contraction equivalent to less than $5 \mathrm{~mm}$, about 10 per cent or less than that for an active anaphylatoxin preparation. In this respect, the range of effective quantitation is markedly increased over that for the guinea pig skin-blueing assay. Moreover, the Schultz-Dale procedure is not hampered by the appreciable blank values (ca. 30 per cent) elicited with normal rat serum in the dye technique for estimation of capillary permeability.

The values listed in the tables below under the columns headed "Schultz-Dale response" represent an arithmetic mean of tests with five replicate aliquots. Each aliquot was tested in a volume of $0.2 \mathrm{ml}$. which represents a $1 \rightarrow 2$ dilution with an equal volume of 0.02 M EDTA on each of five successive segments of guinea pig ileum. The assays were performed in a Latin square design involving five preparations and five segments of ileum. This design was also of value in minimizing the effects of tachyphylaxis as emphasized recently by Rocha e Silva and Rothschild (26). 


\section{EXPERIMENTAL RESULTS}

The data in Table I serve as a basis for comparing the efficacy of preformed immune aggregates (PIA) in $\mathrm{C}^{\prime}$ fixation, $\mathrm{C}^{\prime}{ }_{3}$ inactivation, and anaphylatoxin production, ${ }^{5}$ with similar concentrations of antigen and antibody reacting in the presence of fresh rat serum. This comparison was undertaken because of earlier findings which related the aggregating properties of antibody to $\mathrm{C}^{\prime}$ fixing potency (discussed in reference 27). The diminished $\mathrm{C}^{\prime}$-fixing activities of preformed aggregates noted previously in more highly dilute reaction systems with guinea pig $\mathrm{C}^{\prime}(8,27)$ do not seem applicable in the present studies with more concentrated reagents, such as undiluted $C^{\prime}$ and much higher concentrations of antibody ( $c f$. tubes 1 to 5 and 8 to 11). Of more immediate interest are the findings in Table $I$ which demonstrate that approximately similar levels of $\mathrm{C}_{3}{ }_{3}$ are destroyed by the addition of antigen and immune serum as separate reagents or in the combined state as PIA. In addition, the progressive destruction of $\mathrm{C}^{\prime}$ is accompanied by increased anaphylatoxin activity in the supernates. Finally, heat-inactivated rat serum does not serve as a vehicle for producing increased capillary permeability by PIA ( $f$. also reference 28). This finding also negates the possibility that trace levels of immune complexes, possibly dissolved by the serum and not removed by the centrifugation procedure, are responsible for the biological effects observed with the supernates. This interpretation assumes that the solubilizing property of fresh serum for PIA is no greater than that of heated serum, an inference in line with the findings in references 29 and 30, and one that is borne out in subsequent experiments. An additional point of some interest with regard to the tissue fixation of antibody in systemic anaphylaxis is the observation that immune serum, in the absence of antigen (tube 13) showed some destruction of $\mathrm{C}_{3}{ }_{3}$ as well as a slightly enhanced, and possibly significant, capillary permeability effect. This property is attributable to gamma globulin as shown in experiments conducted in this laboratory, as well as those of Bier (31) and Ishizaka and Campbell $(32)^{6}$.

The parallelism provided by the data in Table I with respect to the fixation of $\mathrm{C}^{\prime}$ and anaphylatoxin formation was extended in an experiment designed to compare the efficacy of PIA prepared at equivalence zone and antigen excess ratios. These aggregates were prepared from rabbit anti-pneumococcus Type III serum and the corresponding capsular polysaccharide, SIII. A time course study was undertaken to provide a more detailed basis for comparison with

\footnotetext{
${ }^{5}$ The assumption is made that anaphylatoxin represents a single compound capable of inducing smooth muscle contraction and enhanced capillary permeability. The validity of the assumption that only a single substance is involved in both activities is currently under investigation.

${ }^{6}$ We wish to thank the authors for the privilege of reading this manuscript in advance of publication.
} 
previous studies in a more highly dilute system (8). The results of this experiment as summarized in Table II and Figs. 1 to 4 confirm the many earlier observations in showing an inhibition of $C^{\prime}$ fixation by excess antigen. As was shown with the protein immune system (Table I, $c f$. also Table V), the poly-

TABLE I

Fixation of Complement and Formation of Anaphylatoxin by the Addition of Preformed Immune Aggregates to Rat Serum and by the Interaction of Antigen with Antibody in the Presence of Rat Serum

\begin{tabular}{|c|c|c|c|c|c|c|c|}
\hline \multirow{2}{*}{ Tube } & \multicolumn{2}{|c|}{ Rat serum* } & \multirow{2}{*}{$\begin{array}{c}\text { Incubated for } 37^{\circ} \mathrm{C} .-90 \\
\text { min. with I ml. } \\
\text { containing }\end{array}$} & \multirow{2}{*}{$\mathrm{C}^{\prime} \mathrm{H}_{6}$ fixed } & \multirow[b]{2}{*}{$\mathrm{C}^{\prime} 3 \mathrm{H}_{10}$ lost } & \multirow{2}{*}{$\begin{array}{l}\text { Diameter } \\
\text { of skin } \\
\text { response }\end{array}$} & \multirow{2}{*}{$\begin{array}{l}\text { Schultz- } \\
\text { Dale } \\
\text { response }\end{array}$} \\
\hline & Unheated & $\begin{array}{l}\text { Heated } \\
56^{\circ} \mathrm{C}-30 \\
\text { min. }\end{array}$ & & & & & \\
\hline & $\mathrm{ml}$. & $m l$. & нg. & & & $m m$. & $m m . \ddagger$ \\
\hline 1 & 5.0 & - & 20 PIA $\S$ & 85 & 274 & $13.6 \|$ & 22 \\
\hline 2 & 5.0 & - & 40 PIA & 112 & 290 & 15.2 & 20 \\
\hline 3 & 5.0 & - & 80 PIA & 145 & 465 & 15.7 & 62 \\
\hline 4 & 5.0 & - & 160 PIA & 152 & 530 & 16.9 & 63 \\
\hline 5 & 5.0 & - & 320 PIA & $>162$ & 550 & 16.7 & 54 \\
\hline 6 & - & 5.0 & 80 PIA & & & 6.9 & \\
\hline 7 & - & 5.0 & 320 PIA & & & 8.0 & \\
\hline 8 & 5.0 & - & 20 a-Ea $\llbracket$ & 98 & 207 & 13.6 & \\
\hline 9 & 5.0 & 一 & $40 \mathrm{a}-\mathrm{Ea}$ & 118 & 265 & 15.1 & \\
\hline 10 & 5.0 & - & $80 \mathrm{a}-\mathrm{Ea}$ & 157 & 326 & 15.7 & \\
\hline 11 & 5.0 & - & 320 a-Ea & 164 & 550 & 17.2 & \\
\hline 12 & 5.0 & 一 & 80 a-Ea control & 5 & 45 & 9.0 & \\
\hline 13 & 5.0 & - & 320 a-Ea control & 20 & 321 & 10.1 & \\
\hline 14 & 5.0 & - & Buffer & None** & Nonet; & 8.4 & \\
\hline 15 & - & 5.0 & Buffer & & & 9.1 & \\
\hline
\end{tabular}

* Pool of serum from adult Wistar rats absorbed twice with washed sheep erythrocytes. Each absorption carried out at $0^{\circ} \mathrm{C}$. for 60 minutes with $1.0 \mathrm{ml}$. of packed red cells per 30 ml. of serum.

$¥$ Each number refers to the arithmetic mean of five replicate assays carried out on five successive pieces of ileum from one guinea pig. The term "Schultz-Dale response" is used to identify the type of tissue bath used for the estimations of smooth muscle contraction. The response of these preparations in the present study is not a Schultz-Dale response in the sense which involves the addition of antigen to a segment of sensitized tissue.

$\S$ Micrograms of rabbit anti-Ea $\mathrm{N}$ in the washed specific precipitate containing $\mathrm{Ea}$ at an antibody $\mathrm{N}$ :antigen $\mathrm{N}$ ratio of 10.5:1.

|| Standard error of the difference for these values $=0.94 \mathrm{~mm}$.

II Micrograms of rabbit anti-Ea $\mathrm{N}$ reacted with an equivalent amount of $\mathrm{Ea} N$ at an antibody:antigen $\mathrm{N}$ ratio of $10.5: 1$. In these tubes, the precipitate was formed in the presence of rat serum.

** This tube contained $172 \mathrm{C}^{\prime} \mathrm{H}_{50}$ after incubation at $37^{\circ} \mathrm{C}$. for 90 minutes.

$\ddagger \ddagger$ This tube contained $712 \mathrm{C}^{\prime} 3 \mathrm{H}_{50}$. 
saccharide reactants at equivalence zone ratios also exhibit a progressive increase, with time, in the fixation of $\mathrm{C}^{\prime}$, inactivation of $\mathrm{C}_{3}^{\prime}$ capillary permeability enhancement, and ability to contract guinea pig ileum. In striking contrast, the intensity of each of these four activities is markedly reduced when the configuration of the immune aggregates is altered through the addition of excess antigen (flask B). The loss of hemolytic potency through fixation is diminished

TABLE II

Fixation of Complement and Formation of Anaphylatoxin: Comparative Efficacy of Washed PIA at Ratios Corresponding to Equivalence and Marked Antigen Excess

\begin{tabular}{|c|c|c|c|c|c|c|c|}
\hline$T$ & $\mathrm{C}^{\prime} \mathrm{H}_{50}$ fixed $^{*}$ & $T$ & $\mathrm{C}^{\prime} 3 \mathrm{H}_{\text {so }}$ lost! & $T$ & $\begin{array}{c}\text { Diameter of } \\
\text { skin response }\end{array}$ & $\boldsymbol{T}$ & $\begin{array}{l}\text { Schultz-Daie } \\
\text { response }\end{array}$ \\
\hline $\min$. & & min. & & min. & $m m .8$ & min. & $m m \cdot \|$ \\
\hline \multicolumn{8}{|c|}{ Flask A-preformed SIII-rabbit-anti-SIII aggregates at equivalence zone ratio } \\
\hline 1.90 & 244 & 2.98 & & 2.54 & 10.3 & 2.98 & $7^{\circ}$ \\
\hline 4.92 & 372 & 6.07 & 355 & 5.58 & & 6.07 & $8^{\circ}$ \\
\hline 10.19 & 567 & 11.42 & 600 & 10.84 & 13.3 & 11.42 & $13^{\circ}$ \\
\hline 31.21 & 1183 & 32.62 & 940 & 32.00 & 16.3 & 32.62 & $30^{\circ} \quad 44^{\mathrm{B}}$ \\
\hline 65.08 & 1212 & 66.26 & 1265 & 65.62 & 16.4 & 66.26 & $36^{\circ}$ \\
\hline \multicolumn{3}{|c|}{ preformed } & II-rabbit-an & i-SIII & ggregates in & \multicolumn{2}{|c|}{ SIII excess } \\
\hline 1.61 & $161^{2}$ & 2.87 & 38 & 2.26 & 9.7 & 2.87 & $5^{b}$ \\
\hline 4.71 & 330 & 6.21 & 149 & 5.49 & 9.1 & 6.21 & $4^{b}$ \\
\hline 10.35 & 366 & 11.57 & 113 & 10.96 & 11.4 & 11.57 & $11^{\mathrm{a}}$ \\
\hline $31.51 \pi$ & 373 & 32.73 & 149 & 61.01 & 12.4 & 61.49 & $14 \mathrm{~s}$ \\
\hline $60.0 \pi$ & - & & & 60.00 & 10.3 & 60.00 & \\
\hline $60.0^{* * *}$ & 0 & & 0 & & 10.3 & & \\
\hline
\end{tabular}

Each flask contained $27.5 \mathrm{ml}$. of rat serum plus $5.5 \mathrm{ml}$. of SIII-rabbit-anti-SIII N aggregates $(20 \mu \mathrm{g} . \mathrm{N}$ per $\mathrm{ml}$.) at ratios of antibody $\mathrm{N}$ :SIII approximating equivalence zone $(\mathrm{R}=$ 8.3) and SIII excess $(R=0.1)$.

* The initial number of $\mathrm{C}^{\prime} \mathrm{H}_{50}$ available for these reactions was 1320 .

$\ddagger$ The initial number of $\mathrm{C}^{\prime} 3 \mathrm{H}_{60}$ units available for these reactions was 4400 .

$\$$ Standard error of the difference $=1.5$.

** Fresh rat serum control without PIA.

|| Each superscript identifies the specimens which were assayed with segments of ileum from the same guinea pig.

T $2.5 \mathrm{ml}$. of heated rat serum $\left(56^{\circ} \mathrm{C} .-30 \mathrm{~min}\right.$.) plus $0.5 \mathrm{ml}$. of PIA at SIII excess ratios.

from a maximum of about 1200 to $400 \mathrm{C}^{\prime} \mathrm{H}_{50}$ despite the presence of identical amounts of antibody in the two flasks. This diminution is also associated with less $\mathrm{C}_{3}^{\prime}$ inactivation, an event likewise reflected in the guinea pig skin tests and smooth muscle assays.

The disparate potencies of PIA at equivalence zone and antigen excess ratios with respect to $\mathrm{C}^{\prime}$ fixation and anaphylatoxin formation provide seemingly substantial evidence as to a possible causal interrelationship between the two processes. In an attempt to subject this tentative conclusion to more critical experimental scrutiny, conditions were sought for the possible separation of 


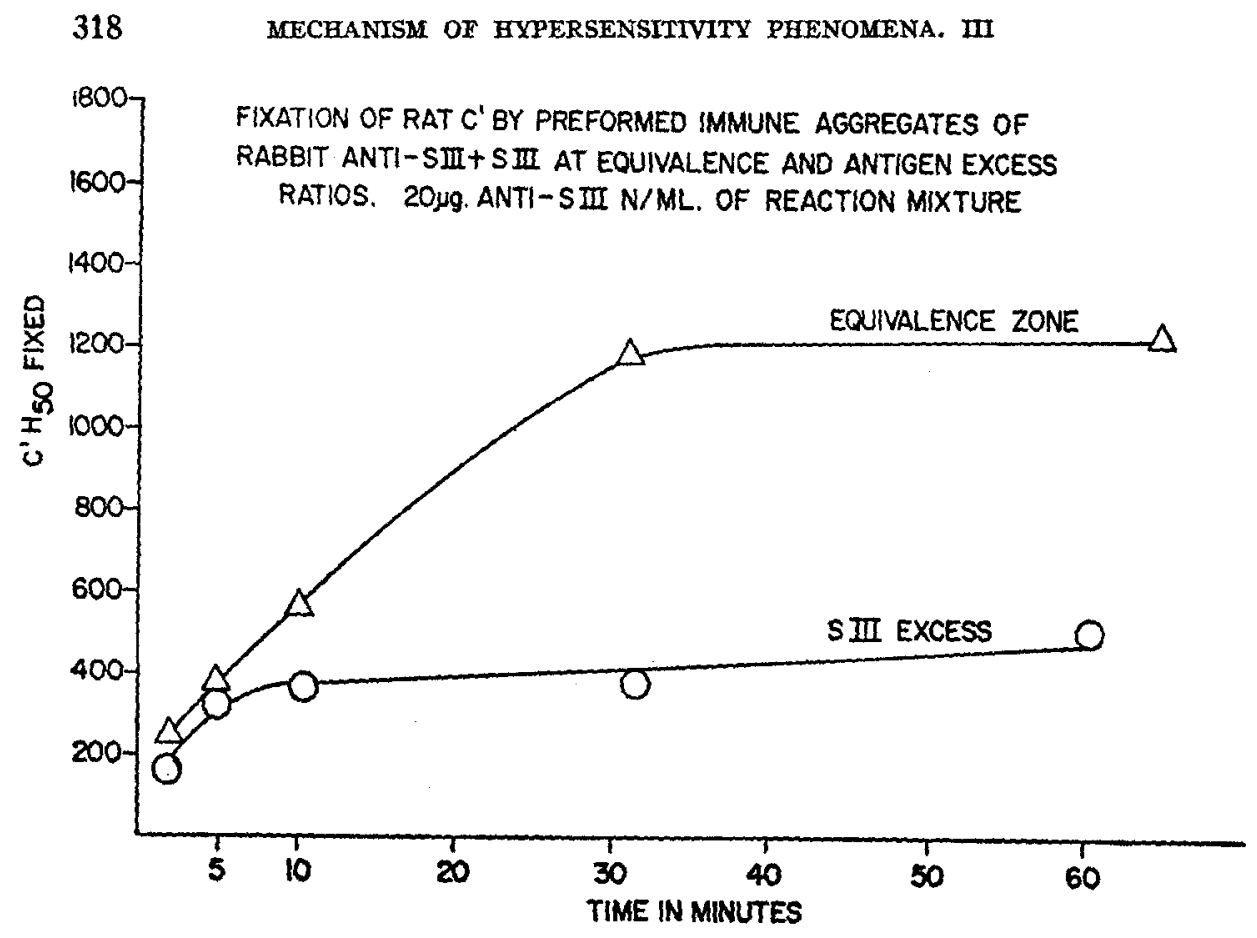

Fo. 1.

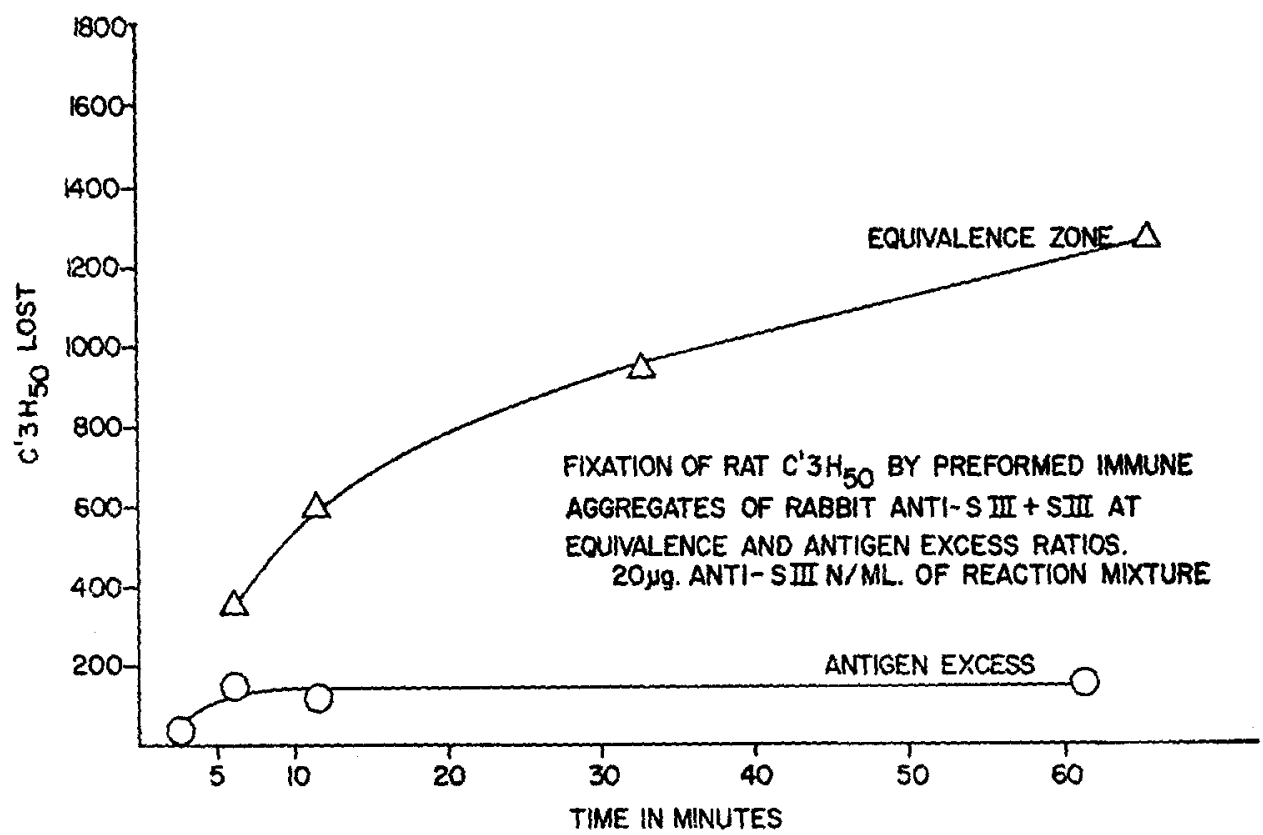

Fig. 2. 


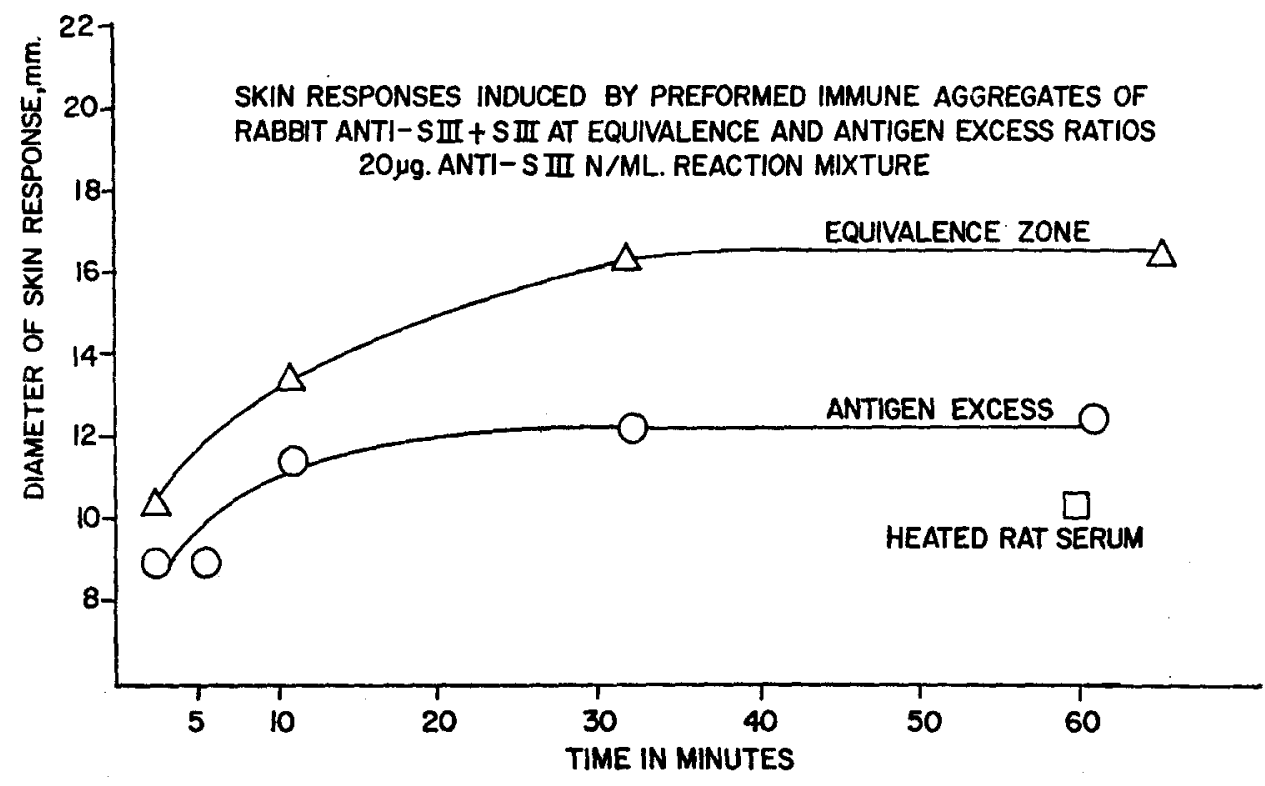

Frg. 3.

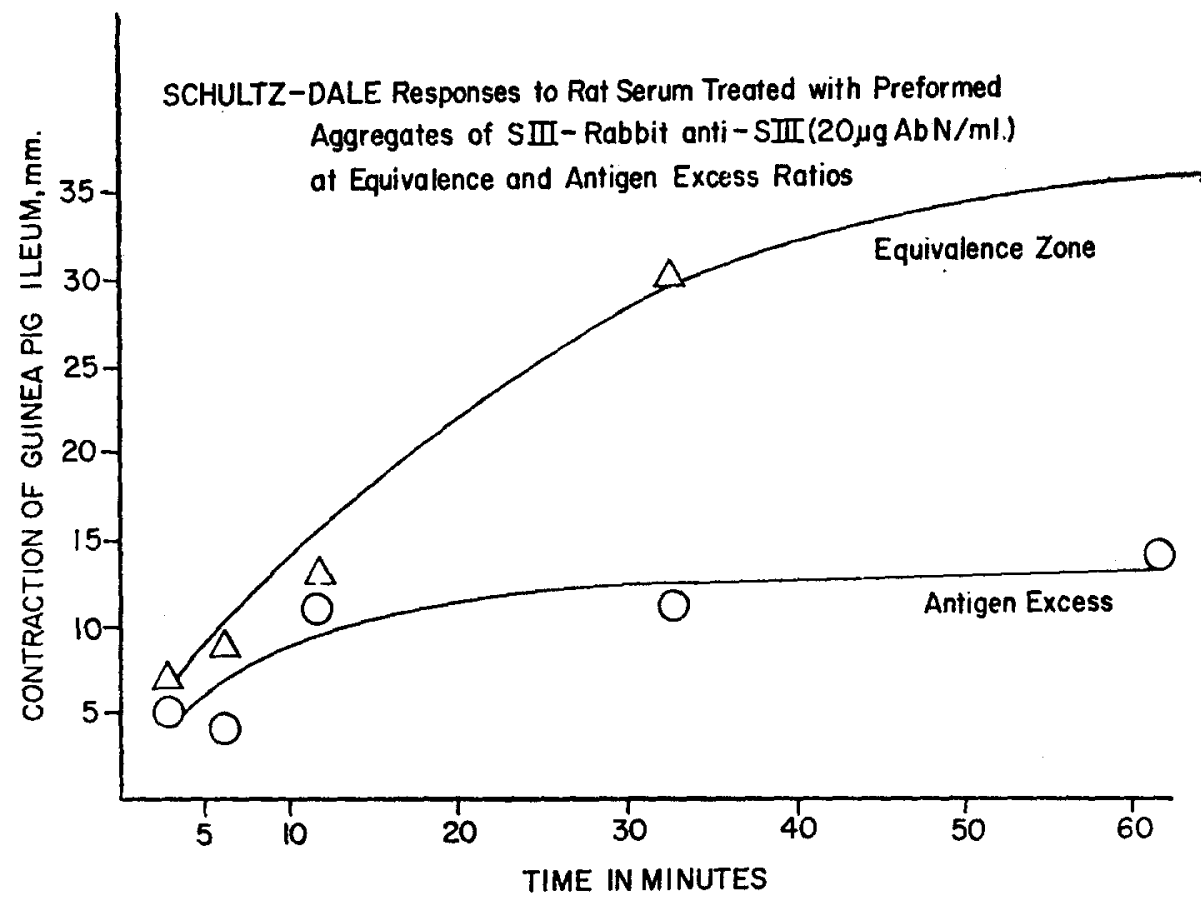

Fig. 4. 
these processes as outlined in a series of experiments summarized by the data in Table III. A study of these results indicates that under certain experimental conditions, the fixation of $\mathrm{C}^{\prime}$ as estimated in terms of a loss in hemolytic activity may occur without initiating anaphylatoxin production, provided the loss in $\mathrm{C}^{\prime}{ }_{3}$ potency is only minimal.

Further, the loss of $C^{\prime}$ component activities through non-immune mechanisms does not seem to mediate significant anaphylatoxin activity, as shown by the data for tubes $1,2,3,9,14,16$, and 18, in Table III. It had been noted previously by Mrs. Eugene Rodriguez of this laboratory, and is presently confirmed, that the hemolytic potency of rat serum is relatively labile to storage in the cold, as compared to guinea pig $\mathrm{C}^{\prime}$. More than 50 per cent of the lytic activity disappeared under these conditions (tube 9) without inducing increased skin blueing or smooth muscle contraction. Neither did treatment of the $\mathrm{C}^{\prime}$ with hydrazine (tube 16), heparin (tube 14), or formalin (tube 18) for the preferential inactivation of $\mathrm{C}_{4}^{\prime}$ or $\mathrm{C}^{\prime}{ }_{3}$ lead to anaphylatoxic activity. The loss of hemolytic activity through specific immune fixation at low temperatures is not an adequate precondition for generating the biological properties under study. Under these conditions, loss in activity may be attributed almost entirely to the interaction of $\mathrm{C}_{1}^{\prime}, \mathrm{C}_{4}^{\prime}$, and $\mathrm{C}_{2}^{\prime}$ with PIA. For example, in tube 10,169 out of 196 , or 86 per cent of the $C^{\prime} H_{50}$ were fixed. In this tube only 152 of 730 units, or 21 per cent of the activity attributed to $\mathrm{C}_{3}^{\prime}$ was lost, a slight augmentation in capillary permeability properties was noted but this was unaccompanied by any increase in the smooth muscle tests. In contrast, the same loss in lytic $\mathrm{C}^{\prime}$ activity was observed in tube 13 , in which fixation was carried out at $37^{\circ} \mathrm{C}$. Under these conditions more than 80 per cent of the $\mathrm{C}_{3}^{\prime}$ activity was destroyed with abundant anaphylatoxin production.

The pertinence of $\mathrm{C}_{3}^{\prime}$ utilization in the mediation of anaphylatoxin production by immune mechanisms, gains increasing interest in the light of the many observations showing that the interaction of this component occurs only after $\mathrm{C}_{1}^{\prime}, \mathrm{C}_{2}^{\prime}$, and $\mathrm{C}_{1}^{\prime}$ have participated in the reaction sequence (18). In line with this reasoning, it was also noted that the destruction of $\mathrm{C}^{\prime}$, by hydrazine, or the destruction of $\mathrm{C}_{3}^{\prime}$ by formaldehyde (tube 19) suffice to arrest or inhibit the full utilization of $\mathrm{C}^{\prime}$ and the consequent formation of anaphylatoxin ( $c f$. also references 33 and 34).

The results obtained with the reaction mixtures in tubes 10 and 12 are also of interest with respect to the mechanism of anaphylatoxin production. In tube 10 , incubation of rat serum with PIA at $0^{\circ} \mathrm{C}$. yielded almost complete $\mathrm{C}^{\prime}$ fixation (169 out of $196 \mathrm{C}^{\prime} \mathrm{H}_{50}$ ) in terms of loss in hemolytic potency with little or no $\mathrm{C}_{3}^{\prime}$ destruction or anaphylatoxin production. When PIA were added a second time as in tube 12 , presumably much of $\mathrm{C}_{1}^{\prime}, \mathrm{C}_{4}^{\prime}$, or $\mathrm{C}_{2}^{\prime}$ had been rendered unavailable, yet that fraction which remained apparently sufficed to initiate marked $\mathrm{C}_{3}^{\prime}$ destruction, enhanced capillary permeability and Schultz- 
TABLE III

Fixation of Complement and Formation of Anaphylatoxin: Effect of Temperature and Availability of $C^{\prime}$ Components

\begin{tabular}{|c|c|c|c|c|c|}
\hline Tube & Treatment of rat serum & $\mathrm{C}^{\prime} \mathrm{H}_{\mathrm{so}}$ fixed & $\mathrm{C}^{\prime} 3 \mathrm{H}_{60}$ lost & $\begin{array}{c}\text { Diameter of } \\
\text { skin response }\end{array}$ & $\begin{array}{c}\text { Schultz-Dale } \\
\text { response }\end{array}$ \\
\hline & & & & $m m .8$ & $m m$. \\
\hline 1 & None & 0 & 0 & 6.4 & \\
\hline 2 & Incubated $60 \mathrm{~min}$. at $0^{\circ} \mathrm{C}$. & 13 & 10 & 6.7 & \\
\hline 3 & Incubated $60 \mathrm{~min}$. at $37^{\circ} \mathrm{C}$. & 44 & 39 & 7.1 & \\
\hline 4 & Plus PIA, 60 min. at $0^{\circ} \mathrm{C}$. & 36 & 38 & 6.8 & \\
\hline 5 & Plus PIA, 60 min. at $15^{\circ} \mathrm{C}$. & 113 & 139 & 10.3 & \\
\hline 6 & Plus PIA, 60 min. at $37^{\circ} \mathrm{C}$. & 187 & 371 & 13.0 & \\
\hline 7 & $\begin{array}{l}\text { Plus PIA, } 60 \text { min. at } 0^{\circ} \mathrm{C} \text {; } \\
\text { centrifuged and incubated } \\
60 \text { min., } 37^{\circ} \mathrm{C} \text {. }\end{array}$ & 98 & 96 & 6.5 & \\
\hline 8 & $\begin{array}{l}\text { Same as tube } 7 \text { but PIA added } \\
\text { again and incubated } 60 \\
\text { min., } 37^{\circ} \mathrm{C} \text {. }\end{array}$ & 186 & 409 & 12.6 & \\
\hline 9 & Incubated $18 \mathrm{hrs}$. at $0^{\circ} \mathrm{C}$. & 100 & 78 & 8.0 & $4 *$ \\
\hline 10 & $\begin{array}{l}\text { Plus PIA, incubated } 18 \text { hrs., } \\
0^{\circ} \mathrm{C} \text {. }\end{array}$ & 169 & 152 & 11.2 & $5^{*}$ \\
\hline 11 & Incubated $60 \mathrm{~min} ., 37^{\circ} \mathrm{C}$. & $\mathbf{0}$ & 0 & & 54 \\
\hline 12 & $\begin{array}{l}\text { Same as tube } 10 \text {, then centri- } \\
\text { fuged; PIA added again } \\
\text { and incubated } 60 \mathrm{~min} \text {. at } \\
37^{\circ} \mathrm{C} \text {. }\end{array}$ & 192 & 510 & 15.9 & 27* \\
\hline 13 & Plus PIA, 60 min., $37^{\circ} \mathrm{C}$. & 170 & $>600$ & 17.0 & $31^{\mathrm{a}} 45^{\mathrm{b}}$ \\
\hline 14 & $\begin{array}{l}\text { Heparin (100 mg.), } 60 \mathrm{~min} . \text {, } \\
37^{\circ} \mathrm{C} \text {. }\end{array}$ & 0 & 295 & 6.6 & $0^{b}$ \\
\hline 15 & Same as tube 14 plus PIA & 73 & 450 & 12.9 & $13^{\mathrm{b}}$ \\
\hline 16 & $\begin{array}{l}\text { Hydrazine, } 0.036 \mathrm{M}, 60 \mathrm{~min} \text {, } \\
37^{\circ} \mathrm{C} \text {. }\end{array}$ & $>190$ & 262 & 8.9 & $5^{b}$ \\
\hline 17 & Same as tube 16 plus PIA & $>190$ & 262 & 8.3 & $6^{\mathrm{b}}$ \\
\hline 18 & $\begin{array}{l}\text { HCHO ( } 0.1 \text { per cent), } 40 \\
\text { min., } 37^{\circ} \mathrm{C} \text {. }\end{array}$ & $>190$ & $>700$ & 7.1 & 0 \\
\hline 19 & Same as tube 18 plus PIA & $>190$ & $>700$ & 5.8 & 0 \\
\hline
\end{tabular}

The PIA consisted of rabbit-anti-Ea + Ea at a level of $20 \mu \mathrm{g}$. of anti-Ea $\mathrm{N}$ per ml. of reaction mixture.

Tubes 1 through 8 , and 9 through 19 represent experiments conducted at different times. All tubes contained $5.0 \mathrm{ml}$. of rat serum in a total reaction volume of $6.0 \mathrm{ml}$.

$* 196 \mathrm{C}^{\prime} \mathrm{H}_{60}$ available.

$\ddagger 494 \mathrm{C}^{\prime} 3 \mathrm{H}_{50}$ available in tubes 1 through 8; 730 in tubes 9 through 19.

$\$$ Standard error of the difference $=0.94$ for tubes 1 through 8 , and 1.3 for tubes 9 through 19. 
Dale response upon renewed addition of the inciting immune reactants. A somewhat similar comparison emerges from the data in tubes 7 and 8 . One interpretation of these data implies that the interaction of all the identified $\mathrm{C}^{\prime}$ components must precede anaphylatoxin formation. This formulation encompasses the findings of Rapp (35) and of Amiraian (36) relative to the pos-

TABLE IV

Fixation of Complement and Formation of Anaphylatoxin: Inhibition by EDTA (Trisodium Ethylene Diaminetetraacetate) and Restoration by Divalent Cations

\begin{tabular}{|c|c|c|c|c|c|c|c|c|c|}
\hline Flask & Treatment & $T$ & $\begin{array}{l}\mathrm{C}^{\prime} \mathrm{H}_{50} \\
\text { Gxed }\end{array}$ & $T$ & $\begin{array}{l}\mathrm{C}^{\prime} 3 \mathrm{H}_{\text {bo }} \\
\text { ixed }\end{array}$ & $T$ & $\begin{array}{c}\text { Diam- } \\
\text { eter of } \\
\text { sinin re- } \\
\text { sponse }\end{array}$ & $T$ & $\begin{array}{l}\text { Schultz- } \\
\text { Dale re- } \\
\text { sponse }\end{array}$ \\
\hline \multirow{5}{*}{ A } & & min. & & min. & & $\min$. & $m m 0^{*}$ & $\min$. & $\mathrm{mm}$. \\
\hline & Rat serum plus & 1.91 & $259 \ddagger$ & 2.47 & 7908 & 2.22 & 11.8 & 2.47 & \\
\hline & preformed im- & 7.94 & 596 & 8.40 & 1460 & 8.18 & 12.2 & 8.40 & \\
\hline & mune aggre- & 28.29 & 834 & 29.36 & 1776 & 28.81 & 14.6 & 29.36 & \\
\hline & gates & 57.28 & 927 & 58.25 & 1850 & 57.70 & 15.0 & 58.25 & $86^{\mathrm{a}}$ \\
\hline \multirow[t]{5}{*}{$\mathrm{B}$} & Same as " $\mathrm{A}$ " & 5.19 & 130 & 6.24 & 350 & 5.59 & 9.9 & 6.24 & $5^{b}$ \\
\hline & $\begin{array}{l}\text { but contain- } \\
\text { ing } 0.01 \mathrm{м} \\
\text { EDTA }\end{array}$ & 20.55 & 117 & 21.41 & 369 & 15.81 & 9.0 & 21.41 & $3^{\mathbf{b}} \quad 0^{2}$ \\
\hline & Then followed & 1.75 & 267 & 2.84 & 630 & 2.19 & 10.5 & 2.84 & $9^{\mathrm{b}}$ \\
\hline & by addition & 11.90 & 585 & 12.97 & 1560 & 12.46 & 13.8 & 12.97 & $48^{\mathrm{b}}$ \\
\hline & $\begin{array}{l}\text { of } \mathrm{Mg}^{++} \text {and } \\
\mathrm{Ca}^{++}\end{array}$ & 30.53 & 518 & 31.63 & 1640 & 31.07 & 14.7 & 31.63 & $44^{\mathrm{b}}$ \\
\hline
\end{tabular}

* Standard error of the difference $=1.8$. Flask $\mathrm{B}-25.0 \mathrm{ml}$. rat serum plus $0.25 \mathrm{ml}$. of 1.0 м EDTA $(\mathrm{pH}=8.0$ ) plus $5 \mathrm{ml}$. of PIA as above. After sample was taken at 20.55 minutes, flask received $0.21 \mathrm{ml}$. of $1.0 \mathrm{M} \mathrm{Mg} \mathrm{Mg}^{++}$and $0.2 \mathrm{ml}$. of 0.01 м $\mathrm{Ca}^{++}$. The next 3 samples were then taken as indicated.

$\ddagger 930 \mathrm{C}^{\prime} \mathrm{H}_{50}$ initially available in $26.5 \mathrm{ml}$. of reaction mixture in flask A which contained $22 \mathrm{ml}$. of rat serum and $4.5 \mathrm{ml}$. of PIA (120 $\mu \mathrm{g}$. anti-Ea $\mathrm{N}$ per ml.). All values corrected to 1000.

$\$ 2370 \mathrm{C}^{\prime} 3 \mathrm{H}_{50}$ available.

sible multiplicity of the reaction involving $\mathrm{C}^{\prime}{ }_{3}$. The temperature requirement for anaphylatoxin production through the utilization of $\mathrm{C}^{\prime}$ is in accord with the observation that of all the known $\mathrm{C}^{\prime}$ components, $\mathrm{C}^{\prime}{ }_{3}$ exhibits the most marked temperature dependency (18). It is also noteworthy that the more rapid genesis of anaphylatoxin at $37^{\circ} \mathrm{C}$. has been reported by many other investigators, an observation that applies as well to the release of histamine and 5-hydroxytryptamine from a variety of tissue preparations by antigen-antibody interaction and other means $(5,37-45)$.

The failure of hydrazine-treated rat serum to yield active anaphylatoxin 
preparations was interpreted on the basis of $\mathrm{C}_{4}^{\prime}$ inactivation by the amine. An attempt was made to confirm this inference through the use of a chelating agent which would deprive the reaction system of the divalent cations required for the interaction of $\mathrm{C}_{1}^{\prime}$ and $\mathrm{C}_{2}^{\prime}$, as well as $\mathrm{C}_{4}^{\prime}$. This experiment is summarized in Table IV and Figs. 5 to 7. In this experiment, flask A contained rat serum and PIA. The contents of flask $B$ were identical except for the addition

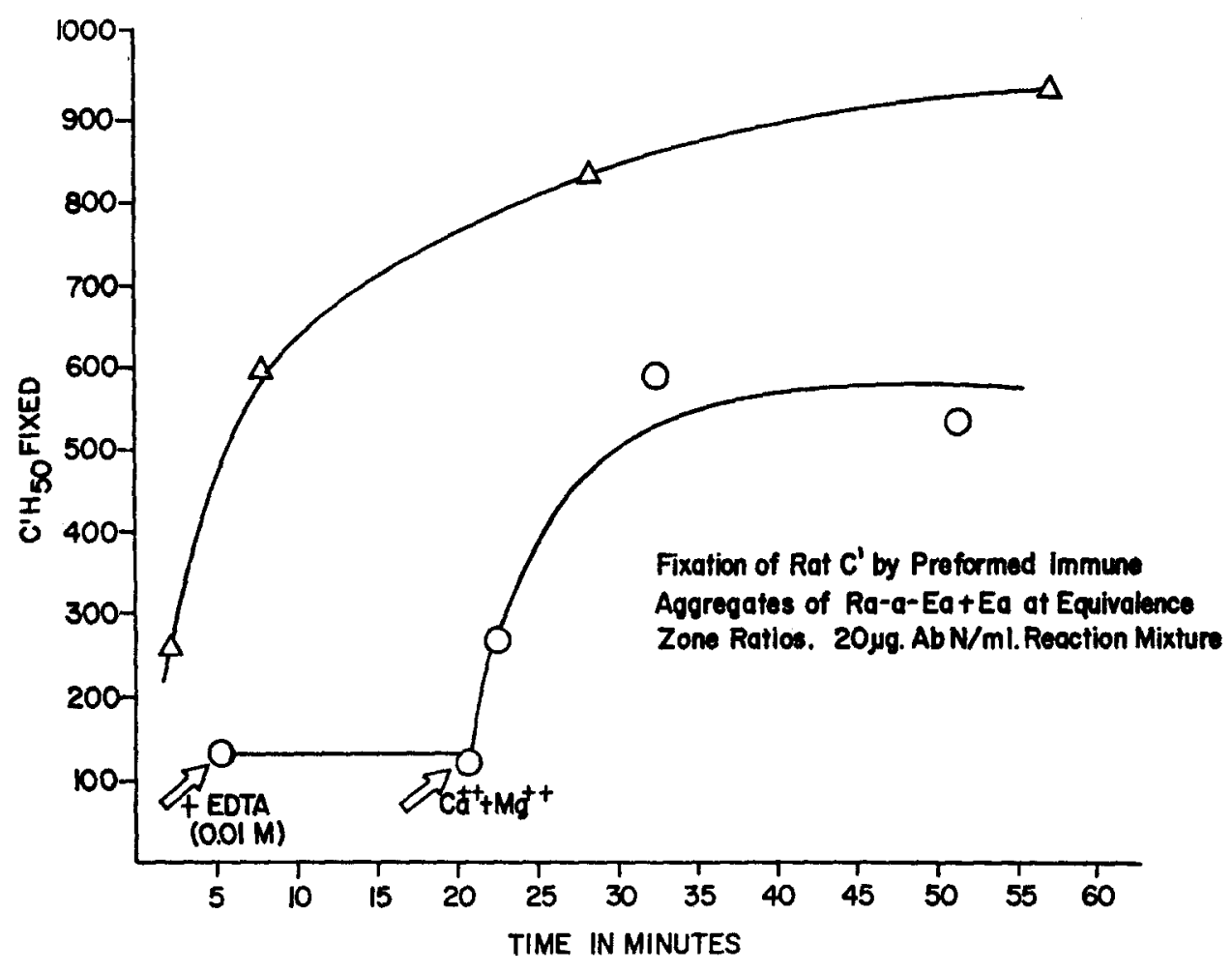

Fro. 5.

of $\mathrm{Na}_{3} \mathrm{HEDTA}$ in a final concentration of $0.01 \mathrm{~m}$. Both flasks were sampled intermittently during a 1 hour interval. When the reaction in flask $B$ had proceeded for about 20 minutes, $\mathrm{Ca}^{++}$and $\mathrm{Mg}^{++}$were added in amounts sufficient to neutralize the effects of the EDTA and in addition, provide a slight excess. As may be noted, the incorporation of these metal ions was rapidly followed by a marked loss of hemolytic activity, inactivation of $\mathrm{C}_{3}{ }_{3}$ and a simultaneous emergence of anaphylatoxic activity. The data in Fig. 7 illustrate the results obtained with one of the segments of guinea pig ileum used for the study of smooth muscle contraction in this experiment. Since $\mathrm{Na}_{3}$ HEDTA in concentrations ranging from 0.002 to $0.016 \mathrm{M}$ had no suppressive 
action on the contraction of guinea pig ileum by preformed anaphylatoxin, it is clear that the processes involving the formation of this substance and the fixation of $\mathrm{C}^{\prime}$ require the presence of divalent cations.

Similar results with respect to the suppressive effect of $\mathrm{Na}_{3}$ HEDTA on $\mathrm{C}^{\prime}$ utilization and skin blueing potency have been observed in other experiments in which anaphylatoxin was generated in guinea pig and in rat serum by the addition of agar. As was also the case with PIA, anaphylatoxin production in

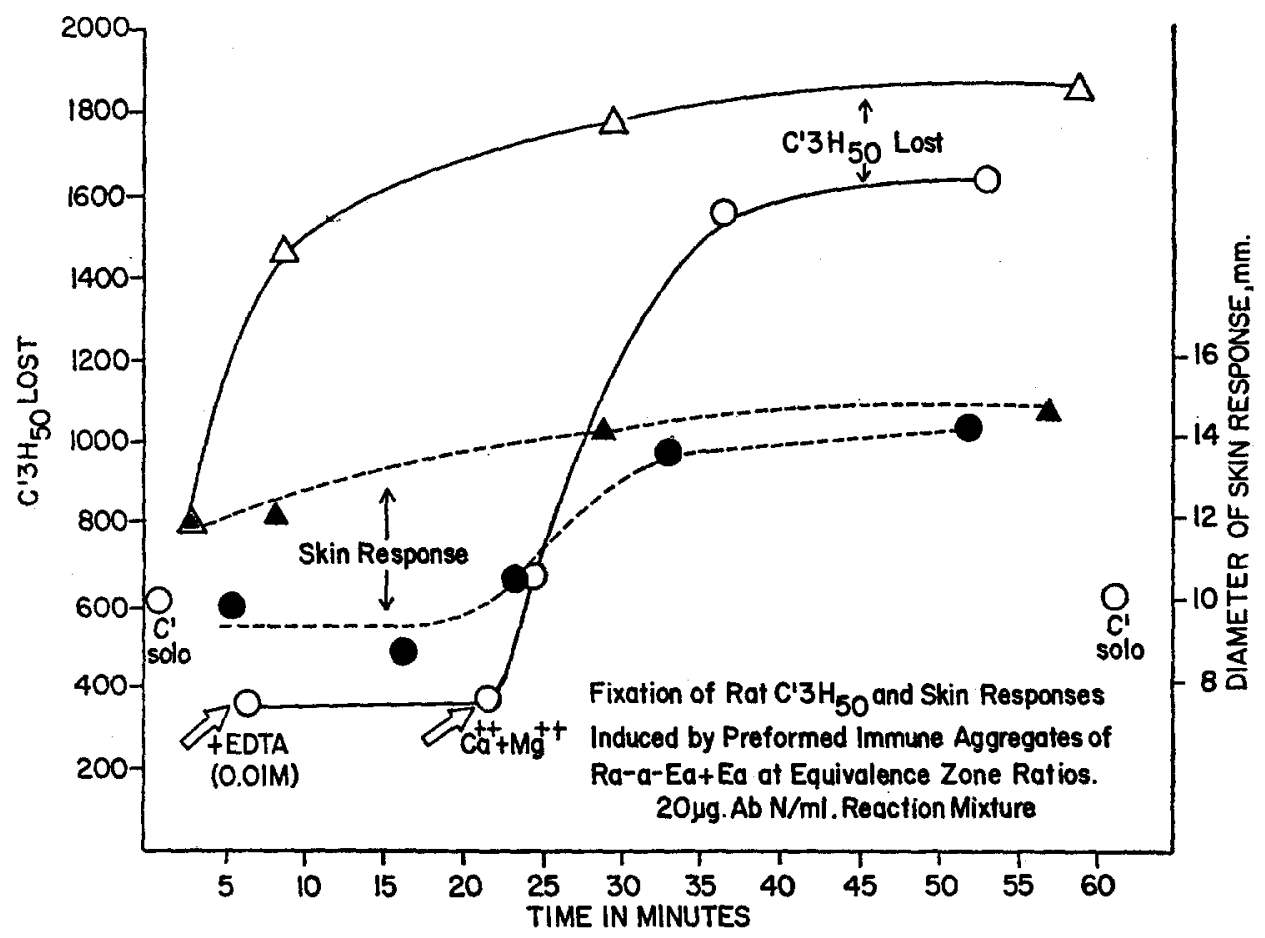

Fig. 6.

rat and guinea pig serum by agar was restored upon the addition of divalent cations.

The significance of the preceding experiment may be ascribed to the demonstration that interference with the utilization of $\mathrm{C}^{\prime}$ by an immune aggregate prior to the uptake of $C^{\prime}{ }_{1}$ and $C^{\prime}{ }_{4}$ simultaneously suppressed the biological activities associated with anaphylatoxin. The soundness of this interpretation with respect to $\mathrm{C}^{\prime}$ participation was tested in a number of experiments designed to inhibit $\mathrm{C}^{\prime}$ utilization at a subsequent step, namely, the utilization of $\mathrm{C}_{\mathrm{z}}^{\prime}$. It had been observed in this laboratory that the glucoside, phlorizin, effectively prevents the participation of $\mathrm{C}_{3}{ }_{3}$ in immune hemolysis (46). Anti- 

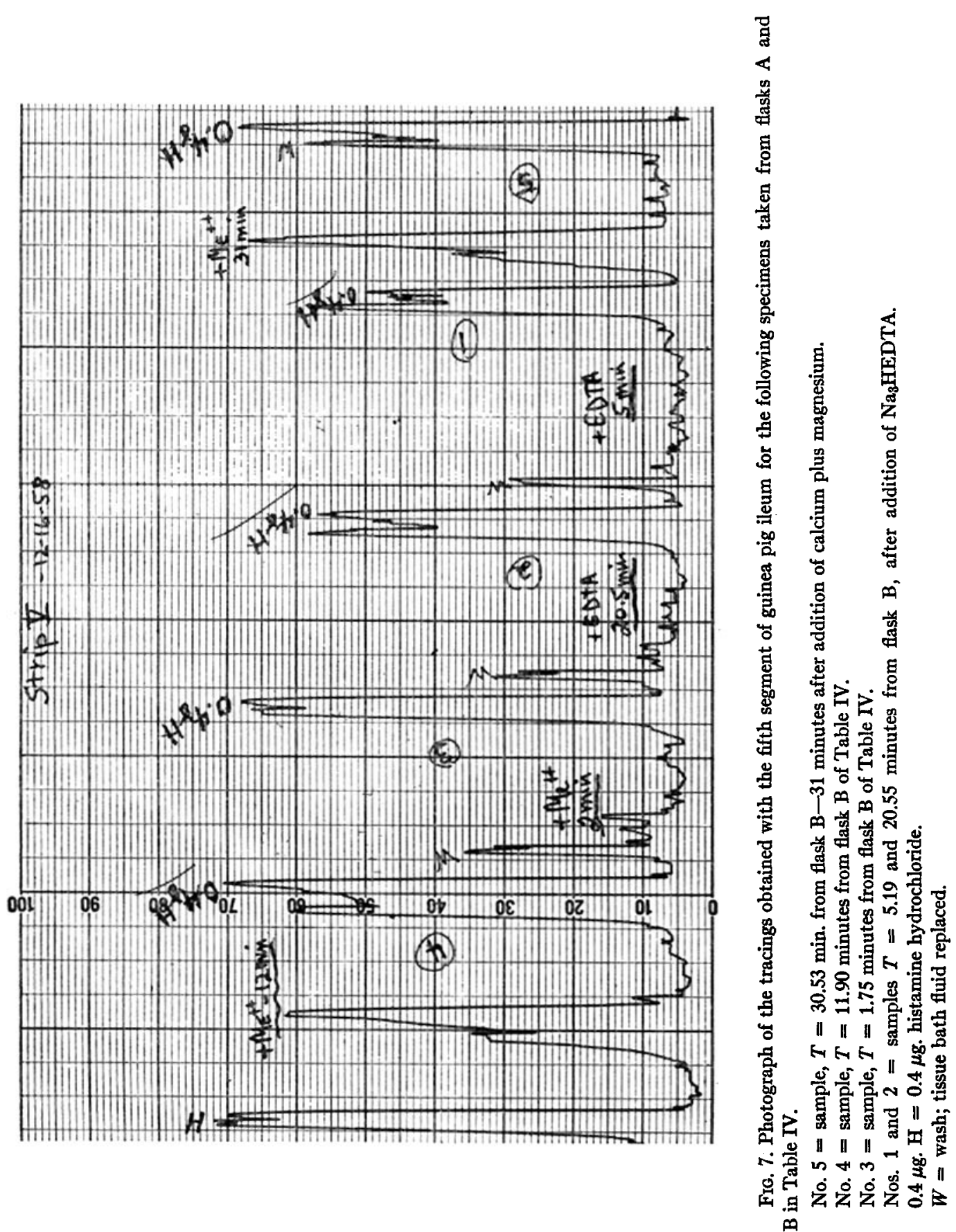
phagocytic properties of phlorizin have also been reported (47 and 47a). Accordingly, the effect of this anticomplementary agent on anaphylatoxin production was investigated with results such as those summarized in Table $\mathrm{V}$ and and Figs. 8 to 10 . A time course study over a 90 minute period showed that the loss in over-all hemolytic activity proceeded with equal rapidity in both

TABLE V

Fixation of Complement and Formation of Anaphylatoxin by Preformed Immune Aggregates: Inhibition by Phlorizin

\begin{tabular}{|c|c|c|c|c|c|c|c|}
\hline$T$ & $\mathrm{C}^{\prime} \mathrm{H}_{\mathrm{BO}}$ fixed & $T$ & $\mathrm{C}^{\prime} 3 \mathrm{H}_{\text {bo }}$ fixed $\ddagger$ & $T$ & $\begin{array}{l}\text { Diameterfof } \\
\text { skin response }\end{array}$ & $T$ & $\begin{array}{l}\text { Schultz- } \\
\text { Dale re } \\
\text { sponse }\end{array}$ \\
\hline min. & & $\min$. & & min. & mm. 8 & $\min$. & $m m$. \\
\hline \multicolumn{8}{|c|}{ Flask $A$-in absence of phlorizin } \\
\hline 1.08 & 669 & 1.35 & 1181 & 1.35 & 11.2 & 1.08 & 3n \\
\hline 3.21 & 1043 & 3.58 & 2542 & 3.58 & 12.9 & 2.85 & $56^{a}$ \\
\hline 5.54 & 1295 & 5.99 & 3316 & 5.99 & 14.4 & 5.06 & $73 \approx$ \\
\hline 9.97 & 1417 & 10.42 & 3639 & 10.42 & 13.8 & 9.57 & 83. \\
\hline 17.96 & 1488 & 18.96 & 3804 & 18.96 & 12.9 & 17.42 & \\
\hline 27.90 & 1530 & 28.50 & 3977 & 28.50 & 14.1 & 27.40 & \\
\hline 54.82 & 1635 & 55.21 & 4206 & 55.21 & 14.5 & 54.51 & $96^{b}$ \\
\hline 90.72 & 1643 & 90.79 & 4270 & 90.79 & 13.8 & 90.23 & $158^{b}$ \\
\hline \multicolumn{8}{|c|}{ Flask $B$-in presence of phlorizin $(0.005 \mathrm{M}) \mathbb{U}$} \\
\hline 1.17 & 774 & 1.44 & 694 & 1.44 & 9.5 & 0.88 & $0^{c}$ \\
\hline 3.30 & 1194 & 3.64 & 1181 & 3.64 & 10.7 & 2.56 & $4^{0}$ \\
\hline 6.32 & 1394 & 6.67 & 1942 & 6.67 & 10.8 & 6.05 & $4^{\circ}$ \\
\hline 10.20 & 1488 & 10.64 & 2264 & 10.64 & 12.1 & 9.70 & $10^{\circ}$ \\
\hline 19.45 & 1538 & 19.91 & 2437 & 19.91 & 12.3 & 18.86 & \\
\hline 30.01 & 1614 & 30.40 & 2575 & 30.40 & 12.4 & 29.38 & $13^{b}$ \\
\hline 59.64 & 1627 & 60.05 & 2838 & 60.05 & 12.2 & 59.18 & $36^{b}$ \\
\hline 92.59 & 1639 & 93.18 & 2876 & 93.18 & 12.2 & 91.99 & $54^{\mathrm{b}}$ \\
\hline
\end{tabular}

* Total $\mathrm{C}^{\prime} \mathrm{H}_{50}$ available; 1740 in $35 \mathrm{ml}$.

† Total $\mathrm{C}^{\prime} 3 \mathrm{H}_{60}$ available; 5080 in $35 \mathrm{ml}$.

\$ Standard error of the difference $=1.5$.

I Dissolved directly in reaction mixture. ${ }^{b}$, each letter refers to the 5 specimens included in one of the three smooth muscle analyses. Each number represents sum of contractions of 5 trials.

flasks $A$ and $B$, which differed one from the other only in that the latter contained phlorizin at a final concentration of $0.005 \mathrm{~m}$ (see Fig. 8). Cessation of the experiment at this juncture would have failed to demonstrate the simultaneous diminution in the inactivation of $\mathrm{C}_{3}^{\prime}$ (Fig. 9), the lessened enhancement of capillary permeability (Fig. 9), and the marked suppression of the smooth muscle response (Fig. 10).

These data provide striking confirmation to the notion gained from hemolytic studies (46), that the inhibitory activity of phlorizin is directed at a stage in 


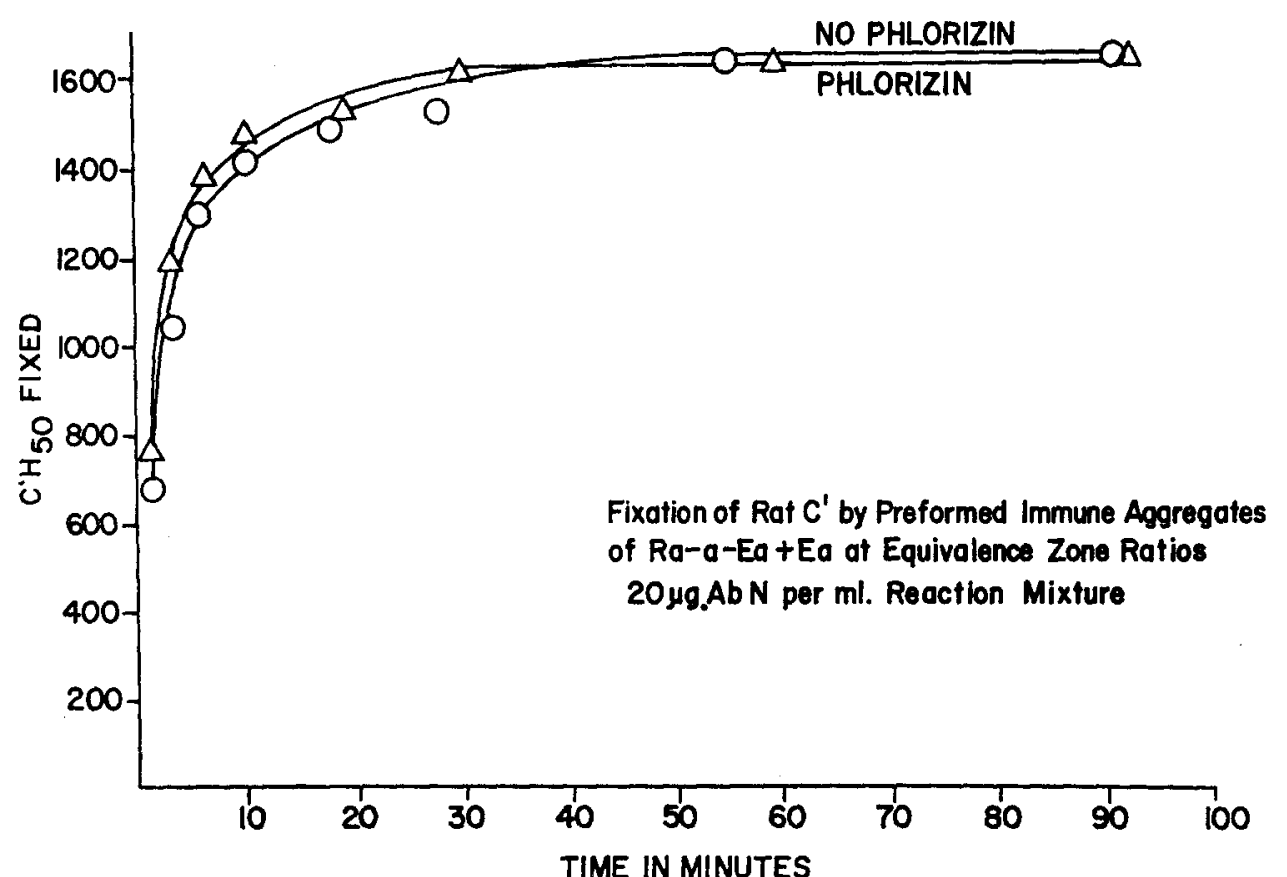

TIME IN MINUTES

Fig. 8.

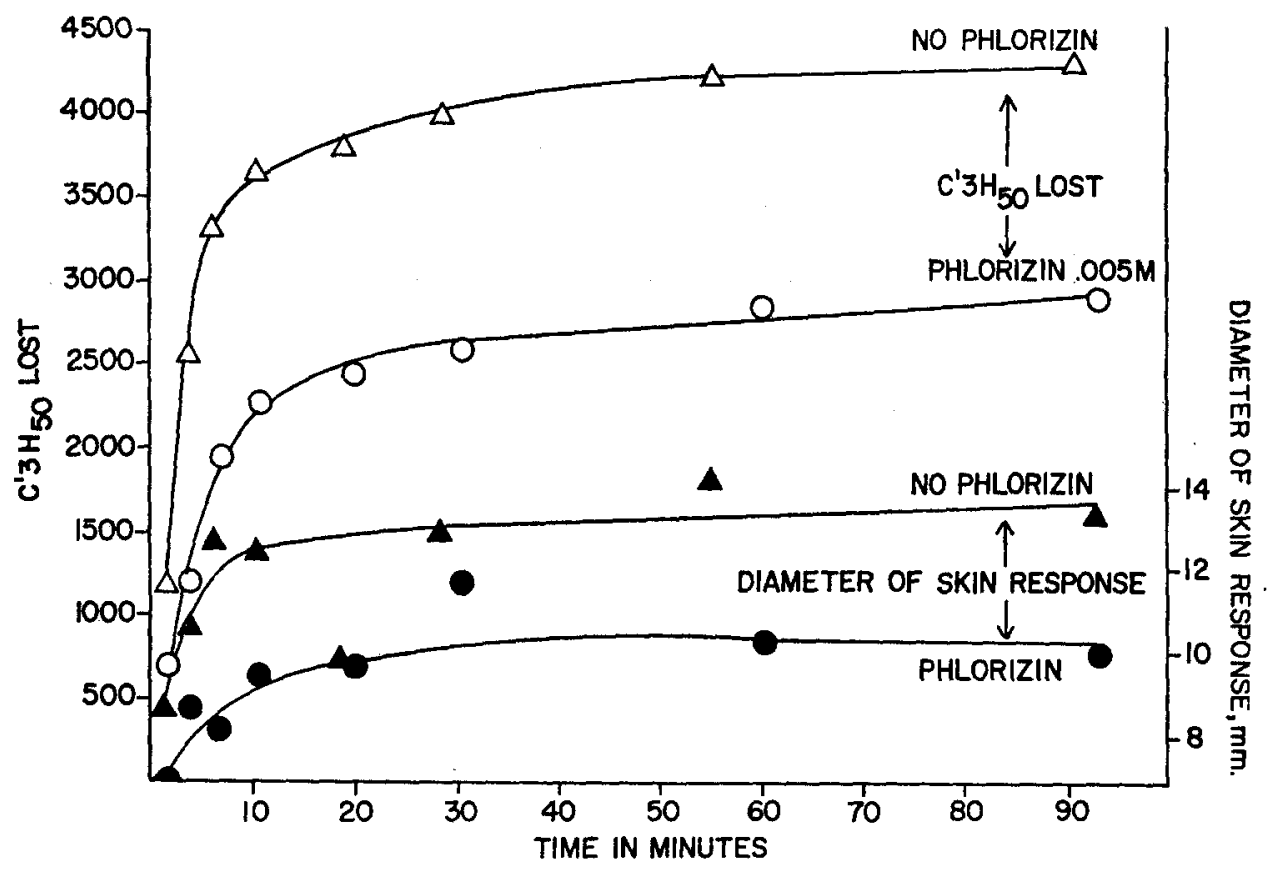

FIG. 9. $\triangle$ O-Fixation of $\mathrm{C}^{\prime} 3 \mathrm{H}_{50}$ from rat serum by preformed immune aggregates of Ea + rabbit-anti-Ea $(20 \mu \mathrm{g}$ antibody $\mathrm{N}$ per $\mathrm{ml}$.); inhibition by phlorizin. $\Delta-$-Skin Responses induced by the $C^{\prime}$ fixation mixtures. 
the lytic process subsequent to the utilization of $C_{1}^{\prime}, C_{4}^{\prime}$, and $C_{2}^{\prime}$. The fixation of these components explains the results depicted in Fig. 8 in showing that the loss of hemolytic activity occurs equally well in both flasks and is not influenced by the presence of phlorizin. The inhibitory properties of this reagent on anaphylatoxin formation and on $\mathrm{C}_{3}^{\prime}$ inactivation by PIA have also been duplicated with agar anaphylatoxin and in guinea pig serum as well.

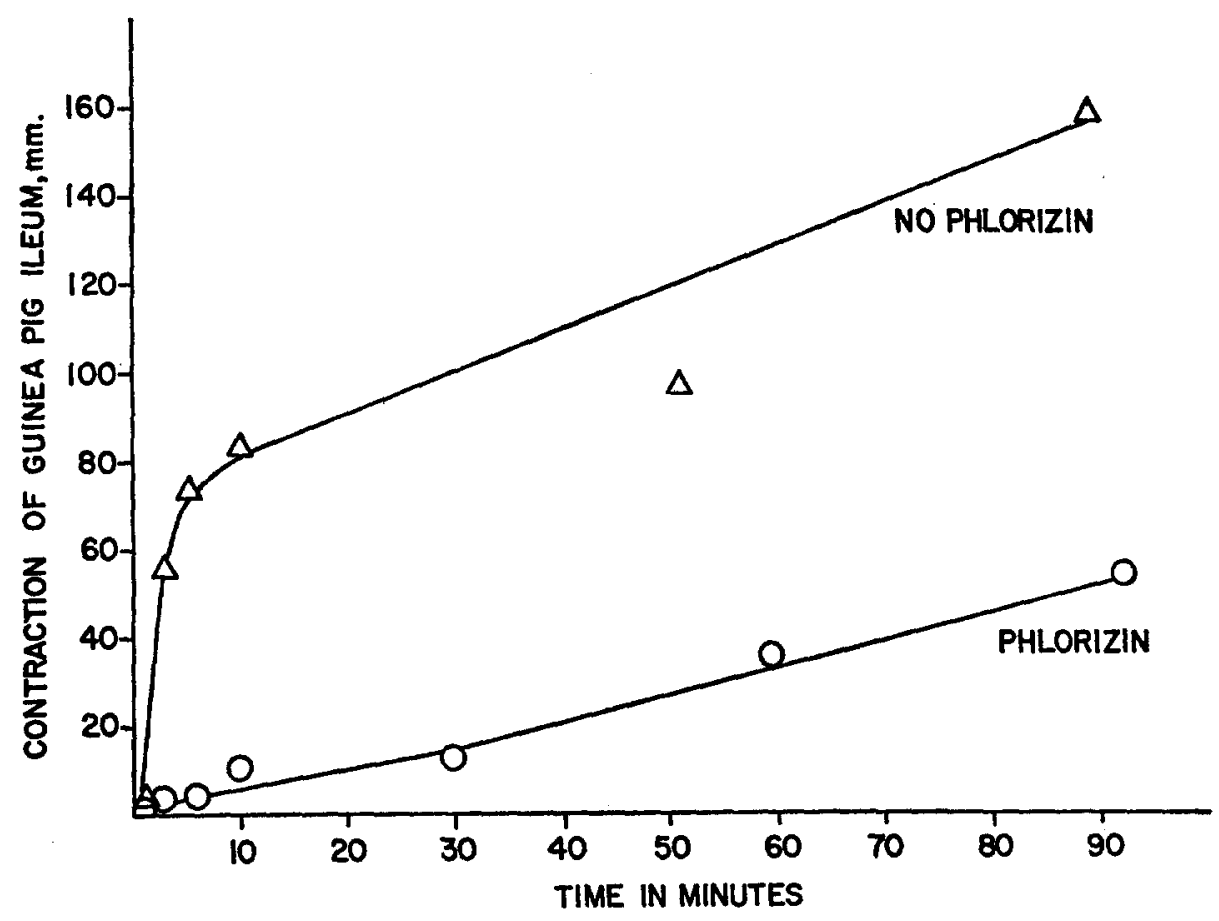

FIG. 10. Schultz-Dale reactions. Rat serum treated with preformed aggregates of rabbit anti-Ea $+\mathrm{Ea}(20 \mu \mathrm{g}$ antibody $\mathrm{N}$ per ml.); inhibition by phlorizin.

Further evidence as to the mechanism of anaphylatoxin formation and its inhibition by phlorizin are provided by the data in Table VI which describes one of several experiments with protein and polysaccharide immune systems. It is apparent that phlorizin exercises its primary action in suppressing the formation of anaphylatoxin. This is indicated by a comparison of the results obtained in tubes 5 and 3 with those of tubes 5 and 4 . The presence of phlorizin at the inception of the immune reaction restrains the production of anaphylatoxin presumably through a bloc at the $\mathrm{C}_{3}^{\prime}$ stage (Table V, Figs. 9 and 10). Once formed, the effect of anaphylatoxin in terms of smooth muscle contraction is almost fully expressed even when phlorizin is added to the SchultzDale bath. It should be pointed out that at concentrations considerably higher 
than those used for the conditions of testing in tubes 3 and 4, phlorizin will partially inhibit the smooth muscle contraction owing to added histamine.

The data in Table VI also indicate the broader range of quantitation provided by the Schultz-Dale experiments as contrasted to the capillary permeability measurements. In the latter case, it is perhaps noteworthy that phlorizin also exerts a suppressive action on the skin blueing of the antibody controls (tubes 1 and 2), in view of the anticomplementary and skin-blueing properties associated with gamma globulin (48 and 49).

TABLE VI

Comparison of the Inhibilory Effect of Phlorizin on Anaphylaloxin Formation and on Smooth Muscle Contraction

\begin{tabular}{|c|c|c|c|c|}
\hline Tube & Reaction mixture & Diluted in & $\begin{array}{c}\text { Schultz-Dale } \\
\text { response }\end{array}$ & $\begin{array}{l}\text { Diameter of } \\
\text { skin response }\end{array}$ \\
\hline & & & mm. & mm. \\
\hline 1 & Ra-anti-Ea & Phlorixinf & 88 & $7.5 \|$ \\
\hline 2 & Ra-anti-Ea & Saline & 17 & 10.5 \\
\hline 3 & $\begin{array}{l}\text { Ra-anti-Ea reacted with } \mathrm{Ea} \text { in } \\
\text { phlorizin }\end{array}$ & Saline & 14 & 10.9 \\
\hline 4 & $\begin{array}{l}\mathrm{Ra} \text {-anti- } \mathrm{E}_{\mathrm{a}} \text { reacted with } \mathrm{Ea} \text { in } \\
\text { saline }\end{array}$ & Phlorizin & 45 & 15.1 \\
\hline 5 & $\begin{array}{l}\text { Ra-anti-Ea reacted with } \mathrm{Ea} \text { in } \\
\text { saline }\end{array}$ & Saline & 49 & 17.0 \\
\hline
\end{tabular}

* These reactions were carried out with $50 \mu \mathrm{g}$. anti-Ea N, $5 \mu \mathrm{g} . \mathrm{Ea} \mathrm{N}$, and $2.5 \mathrm{ml}$. of fresh rat serum at $37^{\circ} \mathrm{C}$. for 90 minutes. Tubes 1 and 2 lacked antigen. Tube 3 contained phlorizin at a final concentration of $0.006 \mathrm{M}$. The reaction mixtures were then diluted in isotonic $\mathrm{NaCl}$ (tubes 2,3 , and 5 ) or in saline containing phlorizin to yield a final concentration of $0.0004 \mathrm{x}$ for the guinea pig skin tests.

$\ddagger$ Final concentration of phlorizin in bath fluid $=0.00003 \mathbf{x}$.

Standard error of the difference $=2.8$.

$\|$ Standard error of the difference $=1.4$.

Much evidence has been accumulated in recent years relating the property of various dextran preparations to the release of histamine and to the induction of anaphylactoid reactions in different hosts and under various experimental conditions (50-60). It was therefore of interest to investigate the anticomplementary activities of these glycosides and the results of these experiments are presented in Table VII. The findings of Taylor and Walton have been confirmed with respect to the ability of dextrans to inhibit complement activity (61). Further, these data may be considered to provide additional evidence for the concept ascribing the intervention of $\mathrm{C}^{\prime}$ and $\mathrm{C}^{\prime}{ }_{s}$ in the chain of reactions leading to capillary permeability enhancement, and induction of smooth muscle contraction. Particular note has been taken of the bimodal variation in the anticomplementary and associated activities with average molecular weight. 
These findings have been duplicated in repeated experiments with different shipments of the same dextran preparations. They serve to emphasize that the average molecular weight, as deduced by light scattering measurements, is not the sole determinant of the anticomplementary property attributed to these dextrans. When the several preparations were dissolved in veronal buffer at a concentration of $15 \mathrm{mg} . / \mathrm{ml}$., it was noted that dextrans 2,6 , and 8 yielded

TABLE VII

Fixation of Complement and Formation of Anaphylatoxin: the Interaction of Dextran with Fresh Rat Serum*

\begin{tabular}{|c|c|c|c|c|c|c|}
\hline \multirow{2}{*}{$\begin{array}{l}\text { Commercial } \\
\text { Solvents Cor- } \\
\text { poration No. }\end{array}$} & \multicolumn{2}{|c|}{ Dextran preparation $\downarrow$} & \multirow{2}{*}{$\mathrm{C}^{\prime} \mathbf{H}_{50}$ fixed } & \multirow{2}{*}{$\mathrm{C}^{\prime} 3 \mathrm{H}_{\text {so }}$ fixed $\mathrm{T}$} & \multirow{2}{*}{$\begin{array}{l}\text { Diameter of } \\
\text { skin response }\end{array}$} & \multirow{2}{*}{$\begin{array}{c}\text { Schultz-Dal } \\
\text { response } \$ \ddagger\end{array}$} \\
\hline & $\begin{array}{c}\text { Average molec- } \\
\text { ular weight }\end{array}$ & O.D. 8 & & & & \\
\hline & & & & & $m m$. & $m m$. \\
\hline & None & & 0 & 0 & 8.0 & \\
\hline 2 & 33,300 & 0.132 & 127 & 520 & 15.2 & $40^{b}$ \\
\hline 3 & 56,400 & 0.011 & 37 & 0 & 8.1 & $2^{\mathbf{b}}$ \\
\hline 4 & 91,700 & 0.015 & 48 & 0 & 9.6 & $6^{\mathrm{a}}\left(1^{\mathrm{b}}\right)$ \\
\hline 5 & 123,900 & 0.012 & 64 & 102 & 13.5 & $9^{a}\left(4^{b}\right)$ \\
\hline 6 & 194,900 & 0.120 & 148 & 566 & 16.7 & $31^{\circ}\left(52^{b}\right)$ \\
\hline 7 & 255,000 & 0.013 & 61 & 101 & 13.2 & $6^{n}$ \\
\hline 8 & 412,000 & 0.119 & 175 & 720 & 17.5 & $35^{\star}$ \\
\hline
\end{tabular}

* Each reaction mixture contained $5.0 \mathrm{ml}$. of fresh rat serum (absorbed twice with sheep red cells) and $100 \mathrm{mg}$. of the designated dextran preparation. The mixtures were incubated for $37^{\circ} \mathrm{C}$. for 60 minutes, centrifuged at $12,000 \mathrm{~g}$ for 20 minutes, and the supernates analyzed.

¥ The authors express their gratitude to the Commercial Solvents Corporation for supplying two series of these dextran preparations, described as predominantly 1 to 6 linkages with 3 to 4 per cent in non-1 to 6 linkages.

\$ Optical density of solution containing $15 \mathrm{mg}$. per ml. of veronal buffer at $400 \mathrm{~m} \mu$ in a Beckman DU spectrophotometer.

$\| 196 \mathrm{C}^{\prime} \mathrm{H}_{50}$ available for the reaction.

Tf $900 \mathrm{C}^{\prime} 3 \mathrm{H}_{\mathrm{b} 0}$ available for the reaction.

** Standard error of the difference is 1.3 .

$\ddagger$ The superscripts ${ }^{*}$ and $b$ refer to each of two different assays.

opalescent solutions, an observation verified by the optical density measurements given in Table VII. It is perbaps of more than casual interest that Kabat and Bezer studied the same dextran preparations as antigens in human beings and reported that a molecular weight of less than 51,000 was not associated with antibody production (62). If the destruction of $\mathrm{C}^{\prime}$ components and production of anaphylatoxin by these dextrans is considered in the light of a specific immune reaction, it would appear that the tendency of these dextrans to aggregate requires further study as one of the variables in addition to the molecular weight characteristics. Thus, when aggregation of the dextrans 
was minimized by careful solution in buffer for a 1 or 2 day period, before addition to the rat serum, the extent of $\mathrm{C}^{\prime}$ destruction was greatly reduced, although the relationships between the preparations were not disturbed. The presence of these complicating factors increases the problem of elucidating the mechanism underlying the action of dextran ( $c f$. reference 50). With respect to the question under study, it is clearly apparent that the $\mathrm{C}^{\prime}$-fixing potencies of the members of this series of dextrans correlate very well with the destruction of $\mathrm{C}_{3}^{\prime}$ and anaphylatoxin formation.

\section{DISCUSSION}

The major objective of this investigation is the design of critical experiments bearing on the participation of $\mathrm{C}^{\prime}$ in the production of anaphylatoxin. In one sense, it may be considered as a continuation of earlier experiments directed towards an evaluation of the role of $C^{\prime}$ in passive cutaneous anaphylaxis (1).

In the latter situation, a series of correlated experiments demonstrated that the cutaneous allergic response could be controlled in a manner entirely comparable to the in vitro $\mathrm{C}^{\prime}$ fixation reaction. In the anaphylatoxin studies, one allergic phenomenon has been transposed to in vitro conditions utilizing a cell-free, fluid reaction system in which the relationship of anaphylatoxin to $\mathrm{C}^{\prime}$ fixation has been brought into sharper definition. As noted previously $(2,3)$, the major difficulty pervading both experimental approaches relates to the methods at hand for the identification of that complex of serum constituents whose sequential action has been grouped in the single term, $\mathrm{C}^{\prime}$.

Through the application of the operational criteria which characterize the properties of $\mathbf{C}^{\prime}$ as gleaned from studies of immune hemolysis (18) and $\mathrm{C}^{\prime}$ fixation in highly dilute systems (27), the evidence now available perhaps provides a more substantial basis for accepting the concept that anaphylatoxin formation may be regarded as one of the consequences of $\mathrm{C}^{\prime}$ fixation in reactions involving the established sequence of all of the known components.

The experimental findings which support this conclusion may be recapitulated in terms of the known properties of $\mathrm{C}^{\prime}$. Thus, the thermal inactivation of hemolytic activity through destruction of the heat-labile components, $\mathrm{C}_{1}^{\prime}$ and $\mathrm{C}_{2}^{\prime}\left(56^{\circ} \mathrm{C} .-30\right.$ minutes) renders serum unsuitable for anaphylatoxin production by immune aggregates, agar, trypanosomes, or other means $(6,37,39,43$, and others). An attempt to distinguish between serum and tissue $\mathbf{C}^{\prime}$ on the basis of thermal inactivation conditions has led some investigators to conclude that $\mathbf{C}^{\prime}$ plays no role in the release of histamine by antigen from sensitized and minced guinea pig lung tissue $(40,41)$. This conclusion may be questioned on two counts. The degree of inactivation of thermolabile components is probably a function of initial concentrations, and since tissue $\mathrm{C}^{\prime}$ has neither been detected nor estimated, the deduction as to its thermolability relative to serum $\mathrm{C}^{\prime}$ would appear premature and possibly unwarranted. 
Further, exposure of the total reaction system involving antigen, antibody, and histamine-containing cells to a temperature of $45^{\circ} \mathrm{C}$. for 20 minutes may produce an irreversible change in the tissue, an effect very likely independent of $\mathrm{C}^{\prime}$ stability, but incapable of resolution in so complex a reaction mixture.

The fixation of $\mathrm{C}^{\prime}$ as a secondary manifestation of aggregate formation has recently been discussed with respect to hemolytic studies (27). The unexpected findings with dextran (Table VII) are provocative in this connection. In addition, the findings in Table II (Figs. 1 to 4) show that anaphylatoxin production is likewise influenced by the ratio of antigen to antibody and structure of the immune aggregate. This is regarded as important contributory evidence to the concept of $\mathrm{C}^{\prime}$ participation in allergic phenomena and has recently received independent confirmation in the studies of Ishizaka, Ishizaka, and Campbell (63) ${ }^{7}$. These investigators report that the capacity of soluble BSA-anti-BSA complexes to enhance capillary permeability, and to fix $\mathrm{C}^{\prime}$, was lost when the composition of these complexes attained the limiting molar ratio, $\mathrm{Ag}_{2} \mathrm{Ab}$, in marked BSA excess. Of similar import in the present connection is their finding that simple hapten-antibody complexes lack both skin activity and the capacity to fix $\mathrm{C}^{\prime}$.

Throughout the conduct of this investigation, it became increasingly apparent that the biological activities associated with anaphylatoxin were better correlated with $\mathrm{C}^{\prime}{ }_{3}$ utilization than with the over-all loss in hemolytic $\mathrm{C}^{\prime}$ potency which may occur following the fixation of $\mathrm{C}_{1}^{\prime}, \mathrm{C}_{4}^{\prime}$, and $\mathrm{C}_{2}^{\prime}$, singly or in combination. The failure to follow the fate of $\mathrm{C}_{3}^{\prime}$ may account in part for the inability of numerous investigators over the past few decades to correlate $\mathrm{C}^{\prime}$ activity with disease processes $(64,65)$. Data such as those obtained with tubes 7, 9, 10, and 12 of Table III are pertinent. Thus, in tubes 7, 9, and 10, hemolytic activity was inactivated either through storage of the fresh serum, or treatment with immune aggregates at $0^{\circ} \mathrm{C}$. without substantial losses of $\mathrm{C}^{\prime}{ }_{3}$ or genesis of anaphylatoxin. The further addition of antigen-antibody aggregates and incubation at $37^{\circ} \mathrm{C}$. resulted in marked $\mathrm{C}^{\prime}{ }_{3}$ inactivation, capillary permeability increase, and smooth muscle contraction. With the lytic activity alone as a guide, tubes 10,12 , and 13 would have appeared almost indistinguishable ( $c f$. also reference 27).

In an analogous fashion, the results obtained in tubes 14 and 15 help clarify the conflicting reports on the ability of heparin to inhibit anaphylatoxin formation ( $c f$. references $4,38,39$, and others). Partial inhibition is noted in tube 15 as compared with tube 13 lacking heparin. However, slight alterations in heparin concentration might alter the result in either direction depending on the amount and concentration of $\mathrm{C}_{3}^{\prime}$ available for the reaction, method of measuring anaphylatoxin activity, etc.

Similar considerations apply to the experiments with EDTA and phlorizin

\footnotetext{
${ }^{7}$ The authors are grateful for the opportunity afforded them to read this manuscript before publication.
} 
as simultaneous inhibitors of $\mathrm{C}^{\prime}$ utilization and anaphylatoxin formation (Tables IV and V, Figs. 4 to 9). These data extend the observations in Table III in the demonstration that the interposition of a bloc at any stage in the $\mathrm{C}^{\prime}$ fixation sequence, e.g., before or after the participation of $\mathrm{C}_{1}^{\prime}, \mathrm{C}_{4}^{\prime}$, and $\mathrm{C}_{2}^{\prime}$ (the former, via metal chelation, the latter, with phlorizin) concurrently suppresses the biological manifestations attributed to anaphylatoxin.

The requirement for divalent cations in the interaction of $\mathrm{C}_{1}^{\prime}, \mathrm{C}_{4}^{\prime}$, and $\mathrm{C}_{2}^{\prime}$ with immune complexes (18) is paralleled by the numerous reports showing a similar requirement for the release of histamine from human blood $(66,67)$, from minced guinea pig lung tissues $(45)$, from platelets $(28,39)$ and also for anaphylatoxin production (6).

These findings emphasize the necessity of considering $\mathrm{C}^{\prime}$ in terms of the entire complex of components and their sequence of action. These comments are not directed towards assigning greater importance to one or the other of the $\mathrm{C}^{\prime}$ components in the total process. On the contrary, it appears thus far that the individual steps in the multiple processes which result in the evocation of anaphylatoxin responses are entirely analogous to the reaction sequence described by Mayer and his associates for immune hemolysis (18). The conclusion relative to the participation of $\mathrm{C}^{\prime}$ in these allergic manifestations does not exclude the possibility that other as yet unknown factors, in addition to antigen, antibody, and $C^{\prime}$, may be operative in these experiments. Further studies on the mechanism of anaphylatoxin formation may serve to disclose their presence.

The present set of experiments also demonstrates that the interaction of immune complexes in fresh serum stimulates the production of anaphylatoxin, thus clarifying one of the possible mechanisms of action of soluble complexes $(63,68,69)$. The action of these aggregates has received much study recently in the thought that they may play a significant role in anaphylatic phenomena. Soluble complexes may possess inherent attributes of importance other than the ability to fix $\mathrm{C}^{\prime}$, such as their capacity to fix to tissue sites. In any event, immune complexes fix $\mathrm{C}^{\prime}$ and produce anaphylatoxin. These properties are dependent on the antigen:antibody ratios of the complexes and events of this nature occurring in the bloodstream may also contribute to the total tissue injury associated with anaphylactic reactions.

It may be appropriate to note that the significance attached to the earlier studies of anaphylatoxin by Friedberger, Bordet, and Novy and DeKruif was sharply diminished with the advent of Dale's studies with isolated smooth muscle. This diminution in interest was occasioned in large measure by the results of Dale's investigations which placed greater emphasis on the events at the cellular rather than humoral level ( 70 , see also references 4 to 6$)$. Moreover, the demonstration by Bordet that agar can activate anaphylatoxin, initiated an as yet unfinished series of publications pertaining to the "non-specific" activators which include dextrans, inulin, 
liquoid, starch, zymosan, etc. The earlier experiments, many of which have been summarized in references 71 and 2 led to the use of the term "anaphylactoid" with the implication that the mechanism of anaphylatoxin release under these conditions differs from that induced by antigen-antibody interaction. While this interpretation may prove correct, studies in this laboratory and by Manski $(72,73)$ have shown that dextran, inulin, agar, zymosan, and liquoid activate anaphylatoxin and destroy $\mathrm{C}_{8}^{\prime}$ in the process (3). Further, as shown in this study, the capillary permeability enhancement and smooth muscle contraction mediated by agar have been effectively curtailed by EDTA and phlorizin. These observations as well as the inability of agar to produce anaphylatoxin at low temperatures, in ammonia-treated serum, or in heated serum provide reasonable ground for speculating that the so called "anaphylactoid" phenomena are closely similar to the more familiar immune processes ( $c f$. also references $5,2,3$ ). The observations with respect to $\mathrm{C}^{\prime}$ utilization and anaphylatoxin production by zymosan are also pertinent in this connection $(2,74)$.

As noted above, the role that may be assigned to anaphylatoxin in the totality of events associated with allergic reactions of the immediate type remains to be evaluated. Current appraisal is difficult because of the contradictory conclusions drawn by different investigators.

Halpern and his colleagues have shown that sublethal injections of anaphylatoxin protect guinea pigs against an otherwise fatal, passively induced, anaphylactic shock (75). Greisman has arrived at a diametrically opposed conclusion on the basis of studies with the Schultz-Dale bath (76). The latter are subject to considerable uncertainty because of technical problems with respect to the efficacy of desensitizing guinea pig ileum and the restoration of reactivity solely as a function of time. Further, Mota has claimed that anaphylatoxin does not liberate histamine from mast cells of rats (77), an opinion that is not shared by Keller (51) for rat mast cells, nor by Gemählich and his colleagues (78) for guinea pig cells, or by Rocha e Silva (reviewed in reference 6).

The studies reported by Giertz et al. indicate that anaphylatoxin may only mediate the cytotoxic type of reaction (79). This conclusion is based on experiments with heparin which has been found in this laboratory to inactivate $\mathrm{C}_{3}$ but only to a limited extent, depending on factors such as discussed previously. The failure to inhibit anaphylaxis may therefore not be admissible as conclusive evidence. A possible relationship of anaphylatoxin to hemolytic reactions in human beings may be inferred from the studies of Jandl and Tomalinson (80).

The advantages which accrue from the utilization of a cell-free system involve a greater flexibility in experimental design and thereby facilitate studies directed towards the elucidation of the mechanism underlying the appearance and action of anaphylatoxin. Further, studies directed towards a characterization of this substance(s) from a fluid, cell-free medium can be approached more readily. The fact that anaphylatoxin reproduces the tissue responses deemed characteristic and fundamental to in vivo anaphylactic reactions heightens interest in its continued study. It would appear at this stage of the investigation that an urgent requirement for further advance lies in the purifi- 
cation of $\mathrm{C}^{\prime}$ components (81) and in the development of chemical methods for identifying and estimating anaphylatoxin activity. The application of such procedures in addition to those used in this study might prove of value in defining the significance of anaphylatoxin in the mediation of allergic reactions of the immediate type, and in the soundness of the rationale which aims at circumventing the associated tissue damage through an interference with the fixation of $\mathrm{C}^{\prime}$.

\section{SUMMARY}

The interaction of fresh rat and guinea pig serum with washed preformed immune aggregates has been studied with respect to the loss in hemolytic potency of the serum, diminution of the $\mathrm{C}_{3}^{\prime}$ activity, and appearance of anaphylatoxin.

It has been found that the formation of anaphylatoxin, as judged by its effect on capillary permeability and smooth muscle contraction, is coincident with or subsequent to the fixation of all the known $\mathrm{C}^{\prime}$ components.

Less anaphylatoxin is formed by aggregates formed with excess antigen than those in equivalence ratio combination.

$\mathrm{C}^{\prime}$ fixation, as well as anaphylatoxin production, may be inhibited by chelation of the divalent cations, presumably by interfering with the fixation of $\mathrm{C}^{\prime}{ }_{1}, \mathrm{C}^{\prime}{ }_{4}$, and $\mathrm{C}_{2}^{\prime}$.

Phlorizin suppresses the utilization of $\mathrm{C}_{3}^{\prime}$ in immune hemolysis, $\mathrm{C}^{\prime}$ fixation by antigen-antibody aggregates, and the production of anaphylatoxin. The biological activities associated with the fixation of $C^{\prime}$ are not manifest unless $\mathrm{C}^{\prime}{ }_{3}$ participates in this process at $37^{\circ} \mathrm{C}$. It is concluded that the formation of anaphylatoxin may be regarded as a product of $\mathrm{C}^{\prime}$ fixation.

The authors wish to express their appreciation for the technical assistance of $\mathrm{Mr}$. Clarence R. Stewart, Jr.

\section{BIBLIOGRAPHY}

1. Osler, A. G., Hawrisiak, M. M., Ovary, Z., Siqueira, M., and Bier, O. G., Studies on the mechanism of hypersensitivity phenomena. II. The participation of complement in passive cutaneous anaphylaxis of the albino rat, J. Exp. Med., 1957, 106, 811.

2. Osler, A. G., Randall, H. G., Hill, B. M., and Ovary, Z., Some relationships between complement, passive cutaneous anaphylaxis, and anaphylatoxin, Symposium on The Mechanisms of Hypersensitivity, Detroit, Henry Ford Hospital, 1958, Boston, Little, Brown and Co., 1959.

3. Osler, A. G., The role of complement in the mediation of tissue injury induced by allergic reactions of the immediate type, Proceedings Symposium on Immunopathology, Seelisberg, Switzerland, 1958, Basel, Benno Schwabe and Co., 1959.

4. Rocha e Silva, M., Concerning the mechanism of anaphylaxis and allergy, Brit. Med. J., 1952, 1, 779 . 
5. Burdon, K. L., Present status of the cellular and humoral theories of anaphylaxis, J. Pediat., 1956, 48, 372.

6. Rocha e Silva, M., Histamine-Its role in anaphylaxis and allergy, Springfield, Illinois, C. C. Thomas, 1955, and earlier papers.

7. Hahn, F., and Lange, A., Anaphylatoxin. An old theory of anaphylaxis in a new light, Deutsch. med. Woch., 1956, 81, 1269.

8. Osler, A. G., and Hill, B. M., Kinetic studies of complement fixation. I. A method, II. The role of the aggregating capacity of antibody and its heterogeneity, J. Immunol., 1955, 75, 137, 146.

9. Kabat, E. A., and Mayer, M. M., Experimental Immunochemistry, Springfield, Illinois, C. C. Thomas, 1948.

10. Gitlin, D., Use of ultraviolet absorption spectroscopy in the quantitative precipitin reaction, J. Immunol., 1949, 62, 437.

11. McDuffie, F, C., and Kabat, E. A., A comparative study of methods used for analysis of specific precipitates in quantitative immunochemistry, $J$. Immunol., 1956, 77, 193.

12. Osler, A. G., Strauss, J. H., and Mayer, M. M., Diagnostic complement fixation. I. A method, Am. J. Syph., Gon. and Ven. Dis., 1952, 36, 140.

13. Wallace, A. L., Osler, A. G., and Mayer, M. M., Quantitative studies of complement fixation. V. Estimation of complement-fixing potency of immune sera and its relation to antibody nitrogen content, J. Immunol., 1950, 65, 661.

14. Rapp, H. J., A mathematical theory and analysis of immune hemolysis, Dissertation, Baltimore, Johns Hopkins School of Hygiene and Public Health, 1955.

15. Rapp, H. J., and Sims, M. R., Preparation of an intermediate product of immune hemolysis with formaldehyde-treated complement, Fed. Proc., 1958, $17,531$.

16. Costa Cruz, J. Da, and Azevedo Penna, H. de, Action of formol upon guinea pig alexin, Memorias de Inst. Oswaldo Cruz, 1932, 26, 92.

17. Costa Cruz, J. Da, and Azevedo Penna, H. de, Constitution of alexin and mechanism of specific hemolysis, Mem. Inst. Oswaldo Cruz, 1932, 26, 124.

18. Mayer, M. M., Studies on the mechanism of hemolysis by antibody and complement, Prog. Allergy, 1956, 5, 215.

19. Menkin, V., Studies on inflammation. I. Fixation of vital dyes in inflamed areas, J. Exp. Med., 1929, 60, 171.

20. Cochran, W. G., and Cox, G. M., Experimental Designs, 2nd edition, New York, John Wiley \& Sons, Inc., 1957.

21. Miles, A. A., and Wilhelm, D. L., Enzyme-like globulins from serum reproducing the vascular phenomena of inflammation. I. An active permeability factor and its inhibitor in guinea pig serum, Brit. J. Exp. Path., 1955, 36, 71.

22. Wilhelm, D. L., Miles, A. A., and Mackay, M. E., Enzyme-like globulins from serum reproducing the vascular phenomena of inflammation. II. Isolation and properties of the permeability factor and its inhibitor, Brit. J. Exp. Path., 1955, 36, 82.

23. Randall, H. G., Neu, H. C., and Osler, A. G., manuscript in preparation.

24. Csapo, A., The relation of threshold to the $\mathbf{K}$ gradient in the myometrium, J. Physiol., 1956, 133, 145. 
25. Talbot, S. A., Lilienthal, J. L., Jr., Beser, J., and Reynolds, L. W., A wide range mechano-electronic transducer for physiological applications, Rev. Scient. Instr., 1951, 22, 233.

26. Rocha e Silva, M., and Rothschild, A. M., Experimental design for bioassay of a material inducing strong tachyphylactic effect (anaphylatoxin), Brit. $J$. Pharm., 1956, 11, 252.

27. Osler, A. G., Quantitative studies of complement fixation, Bact. Rev., 1958, 22, 246.

28. Humphrey, J. H., and Jaques, R., Liberation of histamine and serotonin from platelets by antigen-antibody reactions in vitro, J. Physiol., 1953, 119, 43 P.

29. Maurer, P. H., and Talmage, D. W., The effect of the presence of complement in rabbit serum on the quantitative precipitin reaction. II. Effect on antigen and antibody precipitation, J. Immunol., 1953, 70, 435.

30. Morton, J. I., and Deutsch, H. F., Immunochemical properties of heated ovomucoid, Arch. Biochem. and Biophysics, 1956, 64, 26.

31. Bier, O. G., and Siqueira, M., Passive reversed cutaneous anaphylaxis to protein antigens, Int. Arch. Allergy, 1955, 6, 391.

32. Ishizaka, K., and Campbell, D. H., Biological activity of soluble antigen-antibody complexes. IV. The inhibition of the skin reactivity of soluble complexes and the PCA reaction by heterologous complexes, manuscript in press.

33. Kulka, A. M., Studies on antibody-antigen mixtures. I. Effect on normal living excised tissue, J. Immunol., 1942, 43, 273.

34. Kulka, A. M., Studies on antibody-antigen mixtures. II. The effect on normal living excised tissue and its dependence on the presence of free antibody in the mixture, J. Immunol., 1943, 46, 235.

35. Rapp, H. J., Mechanism of immune hemolysis: recognition of two steps in the conversion of $\mathrm{EAC}_{1,4,2}^{\prime}$ to $\mathrm{E}^{*}$, Science, 1958, 127, 234.

36. Amiraian, K., Plescia, O. J., Cavallo, G., and Heidelberger, M., Complex nature of the step in immune hemolysis involving third component of complement, Science, 1958, 127, 239.

37. Bordet, J., Traité de l'immunité dans les maladies infectieuses, Paris, Masson et $\mathrm{C}^{\mathrm{ie}}, 1920$.

38. Hahn, F., On anaphylatoxin, Int. Arch. Allergy, 1957, 11, 119.

39. Humphrey, J. H., and Jaques, R., The release of histamine and 5-hydroxytryptamine (serotonin) from platelets by antigen-antibody reactions (in vitro), J. Physiol., 1955, 128, 9.

40. Mongar, J. L., and Schild, H. O., Effect of temperature on the anaphylactic reaction, J. Physiol., 1957, 135, 320.

41. Mongar, J. L., Is complement needed in the anaphylactic reaction? Int. Arch. Allergy, 1958, 12, 364 (abstract).

42. Mota, I., Mast cells and anaphylaxis, J. Physiol., 1958, 140, 6 P.

43. Novy, F. G., De Kruif, P. H., and Novy, R. L., Anaphylatoxin and anaphylaxis. I. Trypanosome anaphylatoxin, J. Infect. Dis., 1917, 20, 499.

44. Novy, F. G., and De Kruif, P. H., Anaphylatoxin and anaphylaxis. IV. Agar anaphylatoxin: rat serum, J. Infect. Dis., 1917, 20, 589.

45. Mongar, J. L., and Schild, H. O., The effect of calcium and $\mathrm{pH}$ on the anaphylactic reactions, J. Physiol., 1958, 140, 272. 
46. Rodriguez, E., and Osler, A. G., Studies on the inhibition of immune hemolysis by phlorizin, Fed. Proc., 1958, 17, 533.

47. Puchkov, N. V., The role of glycogenolytic processes in the phagocytic activity of the blood leucocytes, Biokhimiya, 1955, 20, 709.

47a. Ludany, G., Döklen, A., and Toth, E., Influencing leukocyte phagocytosis by means of phlorizin, Experientia, 1957, 13, 409.

48. Davis, B. D., Kabat, E. A., Harris, A., and Moore, D. H., The anticomplementary activity of serum gamma globulin, $J$. Immunol., 1944, 49, 223.

49. Nørgaard, O., Investigations into anticomplementary human serum, Acta Path. et Microb. Scand., 1955, 37, 329.

50. Grabar, P., Reactions de divers serums normaux avec des substances macomoleculaires naturelles ou synthetiques, Ann. Inst. Pasteur, 1955, 88, 11.

51. Keller, R., Tissue mast cells in anaphylactic shock and anaphylactoid reactions, Int. Arch. Allergy, 1957, 11, 328.

52. Haining, C. G., Histamine release in rabbit blood by dextran and dextran sulfate, Brit. J. Pharmacol., 1955, 10, 87.

53. Haining, C. G., Activation of rabbit serum protease by dextran sulphate, Brit. J. Pharmacol., 1956, 11, 107.

54. Haining, C. G., Inhibition of histamine release by sodium salicylate and other compounds, Brit. J. Pharmacol., 1956, 11, 357.

55. Halpern, B. N., Histamine release by long chain molecules, Ciba Foundation Symposium, Histamine, Boston, Little, Brown \& Co., 1956, 92.

56. Rocha e Silva, M., Histamine release by naturally occurring substances, Ciba Foundation Symposium, Histamine, Boston, Little, Brown and Co., 1956, 124.

57. Rocha e Silva, M., Activation by polysaccharides of a histamine liberator (anaphylatoxin) in blood plasma, Symposium, Mechanism of Inflammation, Montreal, 1953.

58. Edlund, T., Löfgren, B., and Väli, L., Toxicity of dextran in rats, Nature, 1952, $170,125$.

59. Morrison, J. L., Richardson, A. P., and Bloom, W. L., Effects of antihistaminic agents on reaction of rat to dextran, Arch. Int. Pharmacodynamie, 1951, 88, 98.

60. Voorhees, A. B., Baker, H. J., and Pulaski, E. J., Reactions of albino rats to injections of dextran, Proc. Soc. Exp. Biol. and Med., 1951, 76, 254.

61. Taylor, C. E. D., and Walton, K. W., The molecular characteristics determining the anticomplementary activity of dextran sulphates, Brit. J. Exp. Path., 1957, 38, 248.

62. Kabat, E. A., and Bezer, A. E., The effect of variation in molecular weight on the antigenicity of dextran in man, Arch. Biochem. and Biophysics, 1958, 78, 306.

63. Ishizaka, K., Ishizaka, T., and Campbell, D. H., Biological activity of soluble antigen-antibody complexes. III. Various antigen-antibody systems and the probable role of complement, $J$. Immunol, in press.

64. Browning, C. H., Critical review. Haemolysis in its clinical aspects, Quart. $J$. Med., 1913, 6, 399. 
65. Weigle, W. O., and Dixon, F. J., Relationship of circulating antigen-antibody complexes, antigen elimination, and complement fixation in serum sickness, Proc. Soc. Exp. Biol. and Med., 1958, 99, 226.

66. Noah, J. W., Symposium, The Mechanisms of Hypersensitivity, Henry Ford Hospital, Detroit, 1958, Boston, Little, Brown \& Co., 1959.

67. Van Arsdel, P. P., Jr., Middleton, E., Jr., Sherman, W. B., and Buchwald, H., A quantitative study on the in vitro release of histamine from leukocytes of atopic persons, $J$. Allergy, 1958, 29, 429.

68. Germuth, F. G., Jr., and McKinnon, G. E., Studies on the biological properties of antigen-antibody complexes. I. Anaphylactic shock induced by soluble antigen-antibody complexes in unsensitized normal guinea pigs, Bull. Johns Hopkins Hosp., 1957, 101, 13.

69. Ishizaka, K., and Campbell, D. H., Biological activity of soluble antigen-antibody complexes. I. Skin reactive properties, Proc. Soc. Exp. Biol. and Med., 1958, 97, 635.

70. Dale, H. H., and Kellaway, C. H., Anaphylaxis and anaphylatoxins, Phil. Tr. Roy. Soc., London, Series B, 1922, 211, 273.

71. Hill, J. H., and Martin, L., A review of experimental studies of non-specific inhibition of anaphylactic shock, Medicine, 1932, 11, 141.

72. Manski, W., and Zylberberg, A., Complement and hemolytic processes in vivo, Bull. Acad. Polonaise Sc. Ser. Sc. Biol., 1957, 5, 295.

73. Manski, W., Vogel, M., and Zylberberg, A., Complement inactivation in vivo and in vitro, Bull. Acad. Polonaise Sc. Ser. Sc. Biol., 1957, 5, 287.

74. Nelson, R. A., Jr., An alternative mechanism for the properdin system, J. Exp. Med., 1958, 108, 515.

75. Halpern, B. N., Liacopoulos, P., and Briot, M., Mecanisme de protection du cobaye contre le choc anaphylactique mortel par l'anaphylatoxine, Acta Allergy, 1956, 10, 9 .

76. Greisman, S. E., The role of anaphylatoxin during in vitro anaphylaxis, J. Immunol., 1958, 81, 214.

77. Mota, I., Anaphylactic shock and anaphylatoxin on mast cells and histamine in rats, Brit. J. Pharmacol., 1957, 12, 453.

78. Gemählich, M., Frenger, W., and Scheiffarth, F., Untersuchungen zur Morphologie der Mastzellen im Anaphylatoxinschock beim Meerschweinchen, Int. Arch. Allergy, 1958, 13, 370.

79. Giertz, H., Hahn, F., Jurna, I., and Lange, A., Zur Frage der Beteiligung des Anaphylatoxins im anaphylaktischen Schock, Int. Arch. Allergy, 1958, 13, 201.

80. Jandl, J. H., and Tomlinson, A. S., The destruction of red cells by antibodies in man. II. Pyrogenic, leukocytic, and dermal responses to immune hemolysis, J. Clin. Inv., 1958, 37, 1202.

81. Borsos, T., and Rapp, H. J., On the action of the second component of guinea pig complement, Fed. Proc., 1959. 